\title{
THE LOCATION OF INDUSTRIAL INNOVATION: DOES MANUFACTURING MATTER?
}

\author{
by
}

\author{
Isabel Tecu \\ Brown University
}

\begin{abstract}
CES 13-09
March, 2013

The research program of the Center for Economic Studies (CES) produces a wide range of economic analyses to improve the statistical programs of the U.S. Census Bureau. Many of these analyses take the form of CES research papers. The papers have not undergone the review accorded Census Bureau publications and no endorsement should be inferred. Any opinions and conclusions expressed herein are those of the author(s) and do not necessarily represent the views of the U.S. Census Bureau. All results have been reviewed to ensure that no confidential information is disclosed. Republication in whole or part must be cleared with the authors.

To obtain information about the series, see www.census.gov/ces or contact Fariha Kamal, Editor, Discussion Papers, U.S. Census Bureau, Center for Economic Studies 2K132B, 4600 Silver Hill Road, Washington, DC 20233, CES.Papers.List@census.gov.
\end{abstract}




\begin{abstract}
What explains the location of industrial innovation? Economists have traditionally attempted to answer this question by studying firm-external knowledge spillovers. This paper shows that firm-internal linkages between production and R\&D play an equally important role. I estimate an $\mathrm{R} \& \mathrm{D}$ location choice model that predicts patents by a firm in a location from R\&D productivity and costs. Focusing on large R\&D-performing firms in the chemical industry, an average-sized plant raises the firm's R\&D productivity in the metropolitan area by about 2.5 times. The elasticity of R\&D productivity with respect to the firm's production workers is almost as large as the elasticity with respect to total patents in the MSA, while proximity to academic $R \& D$ has no significant effect on $R \& D$ productivity in this sample. Other manufacturing industries exhibit similar results. My results cast doubt on the frequently-held view that a country can divest itself of manufacturing and specialize in innovation alone. ${ }^{\mathrm{i}}$
\end{abstract}

\footnotetext{
i $*$ I would like to thank Vernon Henderson for his advice and guidance on this project. I am grateful to Nathaniel Baum-Snow, Andrew Foster, Peter Howitt, William Kerr, Brian Knight, David Weil, and participants of the NBER Productivity lunch, the HBS SBBI seminar, the Brown Applied Micro lunch and Urban lunch for helpful discussions. I am indebted to William Kerr, Shihe Fu, Gerald Carlino, Robert Hunt, and Mohammad Arzaghi for making data available to me, and to Jim Davis for help with Census RDC data. Any opinions and conclusions expressed herein are those of the author and do not necessarily represent the views of the U.S. Census Bureau. All results have been reviewed to ensure that no confidential information is disclosed.
} 


\section{Introduction}

Where companies innovate, and which factors promote local industrial innovation, is a question of enormous interest as the invention of new technologies is the key driver of long-run economic growth. Understanding the role of manufacturing for the location of innovation is particularly relevant as the production of goods over the past decades has increasingly moved out of the US and overseas. Some scholars and industry leaders argue that the development of new technologies depends crucially on familiarity with the production processes of existing technologies, and that, therefore, innovation will eventually follow manufacturing abroad Pisano and Shih, 2009, Liveris, 2011. In this paper, I focus on the location of innovative activity, or research and development (R\&D), of large manufacturing firms in the US and ask to what extent a firm's production sites shape the geography of its innovative activity.

Access to information is a prominent factor for the location of industrial innovation, as demonstrated by a growing literature on knowledge spillovers. The transmission of knowledge, which plays a predominant role in the development of new ideas and inventions, is facilitated by geographic proximity |Jaffe et al. 1993]. In knowledge-intensive industries, including R\&D, firms take advantage of each other's expertise and concentrate geographically Audretsch and Feldman, 1996, Arzaghi and Henderson, 2008, Carlino et al., 2011. Universities and other publicly-funded research institutions also seem to foster local R\&D [Furman et al. 2006.

While these studies have focused on knowledge spillovers from the external environment, they have paid little attention to how firm-internal factors affect where a firm innovates. Geographic proximity, in addition to improving information flows across firms, also fosters communication between the different divisions within a firm Allen, 1977, van den Bulte and Moenaert, 1998. If production and $R \& D$ inform each other, in their decision where to site $R \& D$, firms will take into account the location of production sites. Cross-dependencies between R\&D and production and the consequential co-location of these two activities have long garnered interest in the management literature Kenney and Florida, 1994, Ambos, 2005, Ketokivi and Ali-Yrkkö, 2009]. In a survey on new product development in electronics, Dedrick et al. 2009] observe that manufacturing tends to "pull" the development of new products to factory locations. Pisano and Shih 2009 argue that the manufacturing process is a factor in developing new products in most high-tech industries. 
Firms, then, face a trade-off between locating $R \& D$ in research hubs to take advantage of external knowledge spillovers and locating $R \& D$ close to production to improve internal communication. This trade-off has been explored in the literature, but few papers have studied the relative importance of external spillovers and firm- internal linkages empirically ${ }^{1}$ I show that within the Metropolitan Statistical Area (MSA), a firm's own production plants play an important role for its local R\&D productivity, and that this effect is almost as large as the effect of other innovative activity. Looking only at firm-external knowledge spillovers therefore misses an important aspect of industrial innovation in the United States.

Since there is no data on firm R\&D spending on a detailed geographic level, I use patents as a measure of the firm's innovative activity in an $\mathrm{MSA}^{2}$ I focus on the largest R\&D performing firms in the US, namely multi-unit firms which appear annually in the NSF Industrial R\&D Survey. Of the patenting firms in this sample, more than $70 \%$ patent in more than one MSA, and on average, a firm patents in five different MSAs. As the propensity to patent, as well as the importance of different types of spillovers, varies across industries, I focus most of the empirical analysis on one particular industry, namely "Chemicals and allied products". Section 2 describes the data and the sample I use in greater detail.

In order to investigate the effect on $\mathrm{R} \& \mathrm{D}$ productivity by production sites while controlling for firm-external sources of spillovers, I use a location choice framework. In the model, which I develop in section 3, firms choose whether and how much they invest in R\&D in each MSA. The productivity of the local environment, which I assume to be known to the firm, can then be inferred from its location decisions. Since I observe these R\&D location decisions only indirectly in the form of patents, I combine this location choice model with a stochastic production function for patents which follows a Poisson process [Hausman et al., 1984]. A firm engages in R\&D in a few cities only because of fixed costs, which leads to the estimation of a zero-inflated Poisson model Lambert, 1992 .

\footnotetext{
${ }_{1}^{1}$ Henderson and Ono 2008 analyze the trade-off between proximity to plants and proximity to markets for headquarters of manufacturing firms. Mariani 2002 looks at the decisions of Japanese firms to establish R\&D sites, production sites, or combined R\&D-production sites in Europe.

${ }^{2}$ This is made possible by information on the inventor's residential address, which locates each patent in a particular place, and on the institution that holds the rights to the patents (the "assignee") on a patent application. Corporate patent assignees can be linked to firms in the Census Bureau's Business Register, establishing a dataset of firm establishments and patents in each MSA. I am deeply indebted to William Kerr and Shihe Fu for making their assignee - firm link available to me, and to Gerald Carlino and Robert Hunt for allowing me to use their patent-MSA dataset.
} 
I find that, in the context of the model, a chemical firm's R\&D productivity is about $1.8 \%$ higher if the number of its production workers in the same MSA increases by $10 \%$. Taking an endogenous increase in $\mathrm{R} \& \mathrm{D}$ inputs into account, this corresponds to approximately $10 \%$ more patents by the firm in the MSA. In the average MSA, an average-sized plant raises the firm's R\&D productivity by 2.5 times. Other patents in the MSA have a significant positive effect on the location of patents for firms in my sample, as expected given the evidence on external knowledge spillovers. The size of this effect is on the same order of magnitude as that of the firm's own production workers, suggesting that the scale of production activities is of similar importance for the firm as the overall research environment in the MSA. The elasticity with respect to same-industry employment is half the size of the elasticity with respect to production workers; firm-internal spillovers are therefore more important than spillovers across firms within the same industry.

In my sample, academic R\&D has no significant effect on the location of corporate patents. This result seems to contradict much of the literature but can be explained if firms in my sample locate non-patentable research around universities. I further find that other patents in the same technology classes as the firm's have a positive effect on patenting, while patents in the same industry have a negative effect. Firms that innovate in the same industry and in the same MSA therefore seem to experience detrimental competition effects. My estimation approach is validated by the finding that production workers within a $100 \mathrm{~km}$ around the MSA have a positive effect on the firm's patents inside the MSA, while production workers at greater distances have no effect. The main conclusions are not unique to the chemical industry but hold for other manufacturing industries as well. I verify that my results are robust to alternative definitions of the variables and to alternative specifications of the econometric model.

This paper contributes to the literature in three ways. First, it bridges the gap between the urban economics literature on localized spillovers and the management literature on withinfirm linkages. Firm-external and -internal factors, which are deemed important in either literature individually, together explain the geographic distribution of R\&D more comprehensively. Secondly, the combination of patent and census data allows me to study the determinants of R\&D location on an unprecedented scale. While the trade-off that firms may face in locating R\&D either at research hubs or at production sites has been previously explored, a rigorous empirical analysis has 
not been possible due to a lack of adequate datd 3 . Finally, this paper is innovative in the way that it combines a location choice model with a stochastic R\&D production function of patents. To the best of my knowledge, this is the first paper to connect these two elements and offer a structural economic model to explain the distribution of a firm's patents across MSAs.

Whether firms "bundle" innovation and production activities is an important question in light of their increasingly global structures. If production and $\mathrm{R} \& \mathrm{D}$ tend to locate together, the off-shoring of manufacturing may also induce a loss of know-how and innovative capacity Cohen and Zysman, 1987, Ketokivi and Ali-Yrkkö, 2009, Pisano and Shih, 2009, Liveris, 2011. A global division of labor, in which developed economies specialize in innovation and developing economies in production, may not be as viable as commonly thought.

Within national boundaries, too, cities and regions aim to attract innovative activity because of its associated local externalities. Development of new technologies in a city may lead to faster adoption of these technologies in the same city, increasing productivity, wages, and population Glaeser et al., 1995| 4 As R\&D facilities create jobs for highly-educated people, externalities also operate through human capital. While the magnitude and mechanisms of human capital spillovers are debatable, educated people make better electoral decisions and are less prone to engage in crime Moretti, 2004a b, creating a more attractive and productive environment. If co-location of manufacturing and innovation is important, one strategy for cities to attract innovation, and correspondingly economic growth, may be to attract manufacturing.

\section{Measuring innovation and production within firms}

The lack of readily available data is the greatest impediment to studying within-firm linkages. Broken down to the firm and MSA level, the best information on corporate R\&D stems from patents, which are R\&D outputs. Data on a firm's establishments, although confidential, is available from data gathered by the US Census Bureau. For a sample of firms, a bridge between census files and patent applications lets me track innovation and production sites within the same firm 5

\footnotetext{
${ }^{3}$ See Malecki 1980, Mariani [2002]. Several studies have surveyed firms regarding factors that influence their R\&D location decisions nationally or internationally, e.g. Thursby and Thursby 2006.

${ }^{4}$ The importance of this effect depends on how quickly technology spreads across space. Although the transmission of codified knowledge has become instantaneous, so-called tacit knowledge cannot be communicated remotely, and it is debatable whether this tacit component of knowledge is becoming more or less important.

${ }^{5}$ This bridge has been constructed by Kerr and Fu 2008 .
} 


\subsection{Patents quantify industrial innovation}

According to Title 35 United States Code, any "new and useful process, machine, manufacture, or composition of matter, or any new and useful improvement thereof" is patentable. Patents have therefore frequently been used to measure the output of a firm's R\&D effort: ${ }^{6}$. In contrast to R\&D expenditures and employment figures, patents also provide detailed information on the location of R\&D. A patent application contains the residential address(es) of its inventor(s) and can therefore be assigned to a particular MSA Carlino and Hunt, 2009, Kerr, 2010]7.

The greatest advantage of patent data, as far as this paper is concerned, is that patents trace innovation even if it does not take place in a designated R\&D lab. Looking at the location of R\&D labs only, for example, one does not pick up R\&D performed outside of these dedicated establishment:8. However, about $60 \%$ of patents in my sample occur in MSAs in which the Census' Auxiliary Establishment Survey does not identify an R\&D lab. To study the co-location of R\&D with other establishments, it is crucial to measure $R \& D$ in a way that does not depend on where it is located.

R\&D output and patents are not perfectly correlated. First, not all innovations are patented. Laws of nature and abstract ideas are not patentable, therefore patents do not record all progress in fundamental research. Even if patentable, firms only patent inventions if expected profits outweigh application costs, both in monetary terms and in terms of information disclosure. To the degree that patents measure commercially valuable inventions, as opposed to basic research or inventions of little value to the firm, they reflect the economically most important aspect of R\&D. Different industries, however, face different trade-offs between patents and trade-secrets to protect their intellectual property. In a survey of manufacturing firms, Mansfield [1986] finds that the share of patentable inventions that were patented ranges from $50 \%$ to $86 \%$ across industries. To avoid heterogeneity in terms of how frequently and what types of inventions are patented, I focus the empirical analysis on one particular industry where patents are relatively common, namely Chemicals and allied products

\footnotetext{
${ }^{6}$ see Griliches 1990 for a survey on the use of patents as a measure of technological advancement, and Hall et al. 2001 for a description of this data.

'In interpreting the MSA of a patent as the MSA in which a firm performs R\&D, I assume that inventors live and work within the same MSA. This is a plausible assumption given that MSAs are defined to represent local labor markets. A robustness check confirms that using Consolidated Metropolitan Areas instead yields the same results.

${ }^{8}$ This is a particularly acute problem if one uses census data to identify R\&D labs, since only stand-alone R\&D establishments are recorded as such. The directory "Industrial Research Laboratories of the United States" published by the National Research Council, is another source for R\&D location data, which may be less subject to this problem.
} 
(as defined by SIC code 28)

Second, patents can represent varying degrees of technological advancement. This observation could affect the interpretation of my results: If patents that are located with production sites are less important, the role of production for innovation is overestimated. More generally, the type of $\mathrm{R} \& \mathrm{D}$ that is performed at production sites may be systematically different from the type performed at centralized R\&D labs. Frequently, long-range research concentrates at a central laboratory, while short-term, development-oriented $R \& D$ resides organizationally and physically with business units Steele, 1975, Malecki, 1980, DeSanctis et al. 2002.

Patent citations have proven useful to address heterogeneity in the importance and nature of patented inventions [Harhoff et al., 1999, Akcigit and Kerr, 2010]. I follow this approach and find that weighting patents by the number of citations they received does not alter any results. Furthermore, in the sample I study, patents that are located close to production sites are at least as important, in terms of citation indeces, as patents at R\&D only sites. I find that self-citation shares, measuring the degree to which a patent exploits existing technology ${ }^{10}$, are lower, if anything, for patents that are located close to production sites, compared to patents at R\&D only sites. 11 As long as these limitations are taken into account, then, patents warrant the geographical investigation of industrial innovation, and in particular their co-location with production sites.

\subsection{Linked patent and census data for large R\&D performers}

Patent statistics gain power when they are linked to other information about the patenting firm. While a link between patent assignee firms and the Compustat database has been available for a while, Kerr and others have recently led an effort to match patent assignees to firm identifiers in the census data. Such a link opens up new possibilities for research as census datasets not only include privately-held firms but also detailed information on establishment level ${ }^{12}$

\footnotetext{
${ }^{9}$ According to Mansfield's survey, firms in the chemical and pharmaceutical industries patent $81 \%$ resp. $82 \%$ of patentable inventions. Levin et al. 1987 find that in a survey of high-level R\&D executives, the effectiveness of patents is rated higher in chemicals and drugs than in any other industry.

${ }^{10}$ See Akcigit and Kerr 2010.

${ }^{11}$ Another distinction could be made between product and process R\&D. However, there is no straight-forward way to distinguish between product and process innovation on the basis of patent data since both products and processes are patented.

${ }^{12}$ Patent assignee firms linked to the Compustat database have been a fruitful resource for research Pakes and Griliches, 1980, Lychagin et al. 2010. Compustat is of limited use for me since, except for headquarters, it does not provide information on a firm's establishments and locations. Bridges between patent and census data have been established and described by Kerr and Fu 2008 and Balasubramanian and Sivadasan 2011].
} 
Name-based matches between large patent and census datasets often use geographic information to reduce complexity: Patent assignee "Microsoft" is more likely to be matched to census firm "Microsoft" if both are located in Seattle 13 This mechanism could lead to inflated colocation patterns in the combined dataset. To avoid this inherent bias in large-scale links, I use the link established by Kerr and $\mathrm{Fu}$, which focuses on a small sample of firms that could be matched without the use of geographic information. Details of the applied matching procedure can be found in Kerr and $\mathrm{Fu} 2008$.

The firm sample in this link consists of firms with complete records in the NSF Survey of Industrial Research and Development from 1986 to 1996 and with positive R\&D expenditures in at least one of these years. Firms that enter in the R\&D survey every year generally maintain $R \& D$ expenditures above $\$ 1$ million annually $\sqrt{14}$ and over this period account for about $80 \%$ of total US R\&D expenditures Kerr and Fu, 2008. I further drop from the sample firms that have only one establishment, of which there are few in the link to begin with.

As I assume throughout that firms are unconstrained in their location decisions, large multiunit firms are the appropriate sample to study. For small firms, placing R\&D activity away from the main establishment may not be an option for logistical and financial reasons. Including them in the sample may suggest that there are co-location benefits between manufacturing and R\&D although in reality the co-location arises from constraints on the firm's choice set. Another benefit of looking at firms with stable $R \& D$ expenditures is that I do not have to take firm births or deaths into account. On the down side, restricting the sample to this balanced panel of large R\&D performing companies limits the conclusions that can be drawn. My results have nothing to say about start-ups or small entrepreneurial firms.

For most of the estimations the sample is further restricted to firms in the chemical industry (SIC 28, "Chemicals and Allied Products"), resulting in a sample of 128 firms. Focusing on the chemical industry lends credibility to the estimates because it avoids across-industry heterogeneity in patenting and spillover effects, and because industrial R\&D and patents play an important role in the chemical industry. The firms in this sample employ on average 7000 employees and spend $\$$ 60 million annually on R\&D, of which roughly $90 \%$ is applied research and development and $10 \%$

\footnotetext{
${ }^{13}$ See Thoma et al. 2010] for a survey.

${ }^{14}$ For details on the sampling scheme of the R\&D Survey, see Kerr and Fu 2008.
} 
basic research.

\subsection{The distribution of a firm's patents across MSAs}

The number of patents by firm varies considerably. Table 1 displays the distribution of the number of patents that sample firms apply for over the period 1988-1992, both for the chemical industry and for a pooled sample of other manufacturing industries. Although the sample firms all have large R\&D budgets, $13 \%$ of firms in chemicals and $15 \%$ of firms in other industries do not apply for patents at all. On the other hand, $26 \%$ in chemicals and $13 \%$ in other industries apply for more than 100 patents. Chemical firms file patents more frequently than firms in the other industries: 119 patents in these five years on average, compared to 85.

I next break out a firm's patents by MSA. MSAs are an appropriate spatial unit to use here as they are deliberately defined to capture local labor markets and the assumption that an inventor resides and works in the same MSA, which underlies the interpretation of the patent data, is plausible 15 There are 313 Primary MSAs in the 1990 census definition, which I use here, so that on average a firm has 0.4 patents per MSA ${ }^{16}$ To describe the distribution of patents across MSAs and firms in more detail, I look at two aspects: the number of MSAs in which a firm patents, and the distribution of patents across MSA. First, based on the inventors' addresses the average chemical firm patents in 7 distinct MSAs. Table 2 shows the distribution of this number for the patenting chemical firms in my sample. More than two-thirds of firms patent in more than one and less than 20 MSAs. Only $21 \%$ of chemical firms patent in a single MSA, and $11 \%$ patent in more than 20. Second, as table 3 demonstrates, a firm's patents are unequally distributed across MSAs. Of the seven MSAs in which the average chemical firm patents, three MSAs have 1 patent each, another 3 MSAs have between 2 and 14 patents each, and one MSA has more than 15 patents by the firm. There is considerable variation, then, in whether and how much a firm patents in a given MSA.

Figure 1 illustrates that, not accounting for any other MSA characteristics, patents are more likely to be in an MSA in which the firm operates a production site. The left column shows the

\footnotetext{
${ }^{15}$ Definition of MSA from Census Geography Reference: "A large population nucleus, together with adjacent communities that have a high degree of economic and social integration with that nucleus."

${ }^{16}$ Several Primary MSAs (PMSAs) are aggregated into a Consolidated MSA (CMSAs). Results are robust to using CMSAs as spatial unit.
} 
number of MSAs with and without production sites by the average firm, while the right column shows the number of patents in each type of MSAs. The average chemical firm operates production sites in 10 different MSAs, which constitute 3\% of all possible MSAs. These 10 MSAs contribute $76 \%$ of the firm's patents. The remaining MSAs, which contribute $24 \%$ of patents, may host establishments other than production plants. The large share of patents in the small share of MSAs with plants constitutes preliminary evidence for the co-location of patents and plants. The main estimation needs to control for other sources of knowledge spillovers, however, as they could be correlated with the location of production sites. In the next section I develop a theoretical framework that will serve as the basis for this estimation.

\section{$3 \quad$ A Model for R\&D Location Choice}

Whether production sites generate spillovers for $R \& D$ is a question of whether $R \& D$ is more productive in proximity to production. Answering this question requires information on the productivity of $R \& D$ by a firm in a given location, and on the characteristics of the location. In the absence of information on R\&D inputs by firm and MSA, I cannot simply regress various location attributes on value-added, as studies on agglomeration have done [e.g. Ciccone and Hall, 1996]. Even if data on R\&D inputs were available, however, this approach might suffer from endogeneity as firms choose to locate $\mathrm{R} \& \mathrm{D}$ in places that are more productive.

To deal with the absence of data on R\&D input I follow a structural approach. I formulate a model which uses patents and R\&D input costs rather than input quantities to determine productivity. This assumes that firms choose R\&D inputs in response to local costs and local productivity. In this decision, the firm takes the size and location of manufacturing plants as well as the external environment as fixed. I offer a discussion of this assumption in section 6. I further ignore the strategic aspect of the patenting decision and assume that patents directly measure the quantity of valuable R\&D output produced. 


\subsection{Set-up and Assumptions}

Let $i$ index firms and $m$ index MSAs. I specify the firm's objective as

$$
\max _{\left(L_{i 1}, \ldots, L_{i M}\right)} \sum_{m} E\left[y_{i m}\right]-\sum_{m} C\left(L_{i m}\right)
$$

$y_{i m}$ is the number of patents that the firm produces over a period of time in location $m$. I take patents to be a stochastic outcome, which the firm maximizes in expectation. I use the expected total number of patents as the outcome to be maximized, rather than overall firm profits, to abstract from how the firm capitalizes on a patent - which could be through licensing, improving production processes, or introducing a new product. The assumption that each patent is equally valuable to the firm simplifies the model, and I discuss extensions below 17

The firm's choice variable is the vector of R\&D employees in every location, $\left(L_{i 1}, \ldots, L_{i m}\right)$. $L_{i m}$ determines the expected number of local patents $y_{i m}$ via

$$
E\left[y_{i m}\right]=A_{i m} L_{i m}^{a}, \quad \text { where } \quad 0<a<1 .
$$

$A_{\text {im }}$ denotes the city-firm specific R\&D productivity. The marginal productivity of R\&D labor employed in the city is decreasing. This is a convenient shortcut to explain why firms patent in multiple locations. Results do not hinge on this particular assumption, however, as other explanations for multiple $R \& D$ locations, such as increasing marginal costs of $R \& D$ labor or the complementarity of R\&D labor and productivity spillovers in patenting, would imply the same empirical specification ${ }^{18}$

The cost of using R\&D labor $L_{i m}$ in location $m$ is given by

$$
C\left(L_{i m}\right)=w_{m} L_{i m}+c_{i m}\left[L_{i m}>0\right]
$$

$w_{m}$ is the local wage rate. $c_{i m}$ is a city-firm specific fixed cost for $\mathrm{R} \& \mathrm{D}$, which is incurred whenever the firm engages in $R \& D$ in a location, and which contains regulatory and infrastructure costs, for

\footnotetext{
${ }^{17}$ The value a firm attaches to patents may differ across firms, but these differences cannot be distinguished from differences in R\&D productivity. Firms that value patents more highly will invest more in R\&D, as will firms that are more productive in it. Here, both patent valuation and firm-specific productivity will be captured in the term describing R\&D productivity.

${ }^{18}$ The solution of the model with a CES production function, where $E\left[y_{i m}\right]=\left((1-t) A_{i m}^{g}+t L_{i m}^{g}\right)^{\frac{1}{g}}$, is available upon request.
} 
example. The fixed cost, in combination with decreasing returns in each location, leads firms to concentrate $R \& D$ in a small number of cities, as we saw they do in table 2 .

In this setting, the firm chooses the level of $R \& D$ labor in each city independently, i.e. $L_{i m}$ does not depend on $L_{i n}$. This independence arises because both the value and the costs of patents sum across locations, and so the overall location problem reduces to one problem in each location. The decision of how much R\&D to perform in a given city will depend on the amount of R\&D performed in other cities if firms take their R\&D budget as fixed when deciding on R\&D locations, or if the marginal value of a patent to the firm decreases with the number of patents. Whether a firm performs $\mathrm{R} \& \mathrm{D}$ in a city is then based on the relative rank of that city in terms of $\mathrm{R} \& \mathrm{D}$ productivity net of costs, which makes the estimation approach below infeasible. 19 To illustrate the role of manufacturing for $\mathrm{R} \& \mathrm{D}$ productivity, however, the simple model derived here is sufficient.

The model also uses only one R\&D input factor, labor, the cost of which varies across MSAs and is constant across firms. This assumption could overstate the effect of production on $R \& D$ productivity, if $R \& D$ input costs in fact vary across firms. A model with R\&D capital and labor, which allows capital costs to vary across firms, does not produce significantly different results, however, as appendix B illustrates.

\subsection{The Firm's R\&D Location Decision}

Under the above assumptions, the firm's profit maximization problem is

$$
\max _{\left\{L_{i}\right\}} \sum_{m}\left(A_{i m} L_{i m}^{a}-w_{m} L_{i m}-c_{i m}\left[L_{i m}>0\right]\right) .
$$

The optimal labor in city $m, L_{i m}^{*}$, is

$$
L_{i m}^{*}=d_{i m}\left(a w_{m}^{-1} A_{i m}\right)^{\frac{1}{1-a}}
$$

where $d_{i m}$ is an indicator variable,

$$
d_{i m}=\left[c_{i m} \leq(1-a)\left(a^{a} w_{m}^{-a} A_{i m}\right)^{\frac{1}{1-a}}\right] .
$$

\footnotetext{
${ }^{19}$ The ranking of cities in terms of R\&D productivity net of fixed costs is unobserved, and $E[y]$ does not have a closed form solution in this case. Estimation can only proceed via simulation. Details for this case are available upon request.
} 
The definition of the indicator in equation 6 captures the fact that $L_{i m}^{*}$ is positive if and only if the expected $\mathrm{R} \& \mathrm{D}$ revenue in city $m$ exceeds the fixed cost. If this condition is satisfied, the value of $L_{i m}^{*}$ is determined by the first order condition $\frac{\partial E\left[y_{i m}\right]}{\partial L_{i m}}=w_{m}$.

The expected number of patents at the profit-maximizing amount of R\&D labor, using equation 2 , is

$$
E\left[y_{i m}\right]=d_{i m}\left(a^{a} w_{m}^{-a} A_{i m}\right)^{\frac{1}{1-a}}
$$

The expected patent count $y_{i m}$ therefore depends on firm-city R\&D productivity $A_{i m}$ and costs $w_{m}$

and $c_{i m}$. In the empirical section I estimate the effect of different firm-city level variables on $E\left[y_{i m}\right]$ and back out the effect on R\&D productivity $A_{i m}$.

\section{Estimation}

\subsection{Econometric Specification}

Let $X_{i m}$ be a vector of firm-city characteristics that affect R\&D productivity. I specify that the firm-city specific $R \& D$ productivity is given by

$$
A_{i m}=\exp \left(b_{0}+X_{i m}^{\prime} b\right)
$$

where $b_{0}$ is a constant and $b$ a parameter vector. Plugging this into equations (6) and (7) yields

$$
\begin{aligned}
d_{i m} & =\left[\gamma_{i m} \leq \exp \left(\beta_{0}+\beta_{w} w_{m}+X_{i m}^{\prime} \beta_{X}\right)\right] \text { and } \\
E\left[y_{i m} \mid X_{i m}\right] & =d_{i m} \exp \left(\beta_{0}+\beta_{w} w_{m}+X_{i m}^{\prime} \beta_{X}\right)
\end{aligned}
$$

where I have defined

$$
\begin{aligned}
\beta_{0} & =\frac{a \log a+b_{0}}{1-a} & \beta_{w} & =\frac{-a}{1-a} \\
\beta_{X} & =\frac{1}{1-a} b & \gamma_{i m} & =\frac{c_{i m}}{1-a} .
\end{aligned}
$$

I assume that, conditional on the covariates, $y_{i m}$ follows a Poisson distribution. This is a rather restrictive assumption, but is frequently made in the patent literature. 
I further have to make assumptions on the distribution of the dummy $d_{i m}$, which indicates whether a firm performs R\&D in a given MSA. The observed patents do not completely determine whether a firm performs $R \& D$ in a given MSA: If the patent outcome is zero, the indicator

could be zero or one, as there may be no patents even if the firm does perform R\&D. I assume $\gamma_{i m}=\gamma \exp \left(\nu_{i m}\right)$, where $\gamma$ is a constant and $\nu_{i m}$ is an independent draw from a standard normal distribution, as I want to remain agnostic about the determinants of the fixed cost. The probability that a firm invests into $\mathrm{R} \& \mathrm{D}$ is thus $\left.E\left[d_{i m} \mid X_{i m}\right]=\Phi\left(-\ln \gamma+\beta_{0}+\beta_{w} w_{m}+X_{i m}^{\prime} \beta_{X}\right)\right)$, where $\Phi$ is the standard normal cumulative distribution function.

The expected number of patents in the model to be estimated is, then,

$$
\left.E\left[y_{i m} \mid X_{i m}\right]=\Phi\left(-\ln \gamma+\beta_{0}+\beta_{w} w_{m}+X_{i m}^{\prime} \beta_{X}\right)\right) \exp \left(\beta_{0}+\beta_{w} w_{m}+X_{i m}^{\prime} \beta_{X}\right)
$$

With probability $\Phi\left(-\ln \gamma+\beta_{0}+\beta_{w} w_{m}+X_{i m}^{\prime} \beta_{X}\right)$ the firm does engage in R\&D in the city and the expected number of patents is $\exp \left(\beta_{0}+X_{i m}^{\prime} \beta_{X}\right)$, and with one minus this probability the firm hires no researchers in the city and the expected number of patents is zero. I estimate the parameters $\beta_{0}$, $\beta_{w}, \beta_{X}$, and $\gamma$ using maximum likelihood. The parameters maximize the log-likelihood function

$$
\begin{aligned}
l_{i m} & =\ln \left(\left[y_{i m}=0\right] \Phi\left(\mu_{0}+X_{i m}^{\prime} \mu_{X}\right)\right. \\
& \left.+\Phi\left(-\left(\mu_{0}+X_{i m}^{\prime} \mu_{X}\right)\right) \frac{\exp \left(y_{i m}\left(\beta_{0}+X_{i m}^{\prime} \beta_{X}\right)-\exp \left(\beta_{0}+X_{i m}^{\prime} \beta_{X}\right)\right)}{y_{i m} !}\right) .
\end{aligned}
$$

\subsection{Relation to Poisson and Zero-Inflated Poisson models}

The model derived above is a zero-inflated Poisson (ZIP) model because the possibility of being in state $d_{i m}=0$ generates an excess amount of zeros compared to a simple Poisson model. The simple Poisson model corresponds to the case where fixed costs are zero, i.e. $\gamma=0$, and therefore

$$
E\left[y_{i m} \mid X_{i m}\right]=\exp \left(\beta_{0}+\beta_{w} w_{m}+X_{i m}^{\prime} \beta_{X}\right) .
$$

In general, a ZIP model takes the form

$$
\left.E\left[y_{i m} \mid X_{i m}\right]=\Phi\left(-\mu_{0}-Z_{i m}^{\prime} \mu_{Z}\right)\right) \exp \left(\beta_{0}+W_{i m}^{\prime} \beta_{W}\right)
$$


where $X_{i m}=\left(W_{i m}, Z_{i m}\right)$ Lambert, 1992. In the specific version in equation 12, the variables in the zero-inflation part and those in the Poisson part are identical, i.e. $W_{i m}=Z_{i m}=X_{i m}$, because both the decision to invest in $R \& D$ and how much $R \& D$ labor to employ are determined by $R \& D$ productivity. In addition, the parameter vectors $\mu_{X}$ and $\beta_{X}$ - the opposite sign is a matter of convention - are of identical magnitude. This is a consequence of the assumption that the variables predicting $\mathrm{R} \& \mathrm{D}$ productivity do not affect the fixed costs. If a variable $x$ is allowed to affect the fixed cost of an R\&D lab, such that $\gamma_{i m}=\gamma \exp \left(\nu x_{i m}+\nu_{i m}\right)$, then $\mu_{x}=\nu+\beta_{x}$, i.e. the difference between $-\mu_{x}$ and $\beta_{x}$ is the variable's effect on the fixed cost. Removing the restriction $\beta_{X}+\mu_{X}=0$ is therefore equivalent to allowing the independent variables $X$ to have an effect on the fixed cost.

As robustness checks, I compare results from the specific ZIP model derived above to those from a simple Poisson model, where fixed costs are zero, and to those from the general ZIP model, where the fixed costs could be a function of $X_{i m}$. The differences in the estimated effects across these models are generally insignificant. As the data prefer a model with positive fixed cost ${ }^{20}$, but I do not want to make assumptions about which variables enter into $\gamma_{i m}$, the model with the restrictions $\beta_{X}+\mu_{X}=0$ remains my main specification.

\subsection{Interpretation of the estimated coefficients}

To be able to interpret the coefficients in equation (12), I consider how the expected number of patent changes in response to a change in an independent variables $x$. The elasticity of $E[y \mid X]$ with respect to $x$ is

$$
\eta_{E[y \mid X], x}=\left(\frac{\phi\left(-\ln \gamma+\beta_{0}+\beta_{w} w_{m}+X_{i m}^{\prime} \beta_{X}\right)}{\Phi\left(-\ln \gamma+\beta_{0}+\beta_{w} w_{m}+X_{i m}^{\prime} \beta_{X}\right)}+1\right) \beta_{x}
$$

The first term, $\frac{\phi\left(-\ln \gamma+\beta_{0}+\beta_{w} w_{m}+X_{i m}^{\prime} \beta_{X}\right)}{\Phi\left(-\ln \gamma+\beta_{0}+\beta_{w} w_{m}+X_{i m}^{\prime} \beta_{X}\right)} \beta_{x}$, captures the change in $E[y \mid X]$ through the change in the probability of an $\mathrm{R} \& \mathrm{D}$ investment, and the second term, $\beta_{x}$, captures the change in $E[y \mid X]$ through the change in the expected value conditional on R\&D investment. The elasticity depends on the value of $X$. When the probability of R\&D investment, $\Phi\left(-\ln \gamma+\beta_{0}+\beta_{w} w_{m}+X_{i m}^{\prime} \beta_{X}\right)$, is small, a change in $x$ induces a large relative change in this probability. As the probability of selection approaches 1 , the elasticity converges to $\beta$.

The change in the number of patents induced by a change in $x$, however, contains not only

\footnotetext{
${ }^{20}$ In the data, $98 \%$ of observations have zero patents. Under the Poisson model, given a mean of 0.38 patents, the share of zeros should be around $68 \%$.
} 
the effect of $x$ on $\mathrm{R} \& \mathrm{D}$ productivity but also the endogenous response in $\mathrm{R} \& \mathrm{D}$ inputs. I isolate the effect of $x$ on $\mathrm{R} \& \mathrm{D}$ productivity, defined through $A_{i m}=\exp \left(b_{0}+X_{i m}^{\prime} b\right)$, by translating the coefficients back into the structural parameters,

$$
a=\left(\beta_{w}-1\right)^{-1} \beta_{w} \quad \text { and } \quad b_{x}=(1-a) \beta_{x} .
$$

The elasticity of labor in the $\mathrm{R} \& \mathrm{D}$ production function, $a$, is determined by the wage coefficient $\beta_{w}$. The elasticity of $\mathrm{R} \& \mathrm{D}$ productivity with respect to $x, b_{x}$, can then be computed from $\beta_{x}$ and $a$.

\subsection{Variable definitions and summary statistics}

Table 4 summarizes the variables used in the estimation. The sample consists of 128 firms (those with primary SIC 28 in the R\&D panel, see section 2 that are observed across 313 MSAs, leading to a total of 40,064 observations. Sources and definitions of the variables are detailed in appendix A and appendix table A1. Appendix table A2 contains correlations. Patents by a firm in an MSA are highly serially correlated, therefore I cannot exploit time series variation to identify the effect of plants on patents. Nevertheless, I lag the independent variables to limit the extend to which the estimation results can be driven by reverse causality (I discuss the issue of reverse causality further in section 67. The quality of the firm-patent link is best over the period 1986-1996, and I therefore use plant data from the economic census in 1987,21

The dependent variable $y$, the firm's R\&D output in an MSA, is the number of patents a firm applies for in the 5-year period 1988-1992 with the first inventor residing in the MSA. The average number of patents across all firm-MSAs is 0.4, but this figure masks large heterogeneity in the distribution of patents across cities as already seen in table 3. Conditional on having any patents in the MSA, the average number of patents per firm and MSA increases to about 17 .

The key predictor of interest is firm manufacturing activity in the MSA. I measure it by the number of production workers employed by the firm in the MSA, possibly aggregating several plants. On average a firm operates plants in 10 MSAs with 170 production workers each. This measure of manufacturing activity seeks to exclude research inputs, e.g. research staff working at a plant, since otherwise the effect of manufacturing activity on research output would partially operate

\footnotetext{
${ }^{21}$ In a robustness check I show that the 1992 census delivers the same results.
} 
through the direct relation between research inputs and outputs rather than through productivity. Production workers contribute $55 \%$ of plant employment on average. The remaining $45 \%$ of other employees are not further broken out by function, but could include R\&D staff. By definition, production workers are not hired to perform research 22 but I discuss possible exceptions below. Results are robust to using plant capital stock instead of production workers.

The estimation controls for two measures of external spillovers. The amount of patents in the MSA, outside of the firm, in the previous five years is a direct indicator for how conducive the MSA environment is for innovation. On average there are 538 patents in an MSA over this period, excluding the firm's own. MSA employment in the same 2-digit industry as the firm, excluding the firm itself, measures potential spillovers arising from firms in the same industry ${ }^{23}$ The chemical industry is of considerable size with on average almost 3,000 employees per MSA.

The economic model explicitly includes the MSA wage as independent variable since it determines the unobserved level of R\&D investment. To avoid an endogenously determined variable, the median MSA wage across all sectors except chemicals is used. I will further have to control for MSA population size since congestion cost associated with large MSAs are probably not completely captured by wages. In particular I do not have comprehensive data on rents, which are usually higher in larger MSAs and represent another cost facing R\&D. The average MSA population consists of about 600,000 people, which is driven by a large number of small MSAs.

I also control for overall employment across all US establishments of a firm to capture some of the heterogeneity across firms. Some firms may be inherently more productive in R\&D across all cities, spending more on R\&D generally. Since controlling for the size of the R\&D budget directly may induce endogeneity, I use firm size rather than R\&D expenditures at the firm level; the correlation between firm size and R\&D expenditures is 0.9 in this sample. On average, the firms in the sample employ close to 7000 people in the US.

The remaining variables in table 4 are used to establish further results and will be intro-

\footnotetext{
22 "Included in this item [production workers] are workers (up through the line-supervisor level) engaged in fabricating, processing, assembling, inspecting, receiving, storing, handling, packing, warehousing, shipping (but not delivering), maintenance, repair, janitorial and guard services, product development, auxiliary production for plant's own use (e.g., power plant), recordkeeping, and other services closely associated with these production operations at the establishment covered by the report. Employees above the working-supervisor level are excluded." (Census Online Glossary)

${ }^{23}$ The variation in this variable across firms is negligible since individual firms usually contribute only a small share of total industry employment.
} 
duced below. All independent variables enter the estimation in logarithmic form, except categorical variables and ratios 24

\section{Results}

\subsection{Main results}

Table 5 reports the main estimation results of the zero-inflated Poisson model derived above. The dependent variable is the number of patents by a given firm in a given MSA. The main independent variable is the number of production workers by the firm in the city, which captures the potential firm-internal spillovers from production to R\&D. Other patents in the MSA, other employment in the same two-digit industry in the MSA, median MSA wage outside of the firm's own industry, MSA population and overall firm size are further control variables. The coefficients maximize the likelihood function in (13). Elasticities are computed in table 6 and discussed below.

The preferred specification is the one in column 4 of table 5 , which controls for external spillovers, MSA wage level and size, and firm size. The coefficient on production workers is positive and highly significant, in line with the hypothesis that local production matters for innovation. Other patents and industry employment in the MSA, measuring external spillovers, also bear the expected positive coefficients. MSA population has a negative effect on the firm's patenting, which may surprise given that larger MSAs are usually associated with higher productivity. Rents, however, are also higher in larger MSAs, and may not be entirely controlled for by the wage. In addition, I have already accounted for agglomeration benefits in terms of patents and own industry employment. The negative coefficient on MSA populations therefore captures the higher costs of performing R\&D in larger MSAs, net of wages, patent and industry effects ${ }^{25}$ Firm size, across all MSAs, has a positive effect on the firm's patenting in the MSA. All else equal, larger firms produce more patents in a given MSA, either because they are more productive at it or find it cheaper or both ${ }^{26}$ The MSA wage variable aims to capture the cost of R\&D labor and indeed enters negatively,

\footnotetext{
${ }^{24}$ In the case of variables that take on zero values, I add one to the variable before taking the log. In this case, interpretation of the coefficient changes slightly, but the difference is minuscule for large values of the variable. Variables to which the $\log (x+1)$ transform is applied are either zero or large, such as manufacturing employment by the firm in the MSA, and adding one can be safely ignored when interpreting the coefficients.

${ }^{25}$ Comprehensive data on rent is not easily available. For a subset of MSAs, I find that rent data for central business districts is insignificant in this specification.

${ }^{26}$ For the main interpretation of my results I assume that large firms are more productive. The alternative case
} 
but is imprecisely estimated. The fixed cost parameter, $\gamma$, is estimated to be about 26 , implying that an MSA which produces 26 patents in expectation (conditional on $R \& D$ investment) receives R\&D investment with a $50 \%$ probability.

Columns 1-3 experiment with MSA population and firm size, as these variables do not measure spillover effects directly and one could debate whether they should be included in the main specification at all. In the basic specification in column 1, which just includes the external spillover measures and MSA wage, the coefficient on production workers is the only one that is significantly larger than zero. Adding MSA population to the specification increases the coefficients on other patents so that it becomes significantly greater than zero, both in the case where when firm size is excluded or included (column 2 versus column 1 and column 4 versus column 3). Not controlling for MSA population would therefore blur the spillover effect of other inventive activity with congestion effects of larger MSAs. The coefficient on production workers, however, is not sensitive to the inclusion of MSA population. As the coefficient on production workers drops slightly, though insignificantly, when firm size is controlled for, I control for firm size in the main specification.

To interpret the magnitude of the coefficients, table 6 computes elasticities (equations (17) and (18)). The first column displays the elasticity of the expected number of patents with respect to the various independent variables, computed at the mean using the estimates in column 4 of Table 5. The expected number of patents increases with the number of production workers almost onefor-one. As the expected number of patents is not only affected by R\&D productivity but also by an endogenous response in R\&D inputs, the second column isolates the effect on R\&D productivity. The value of 0.18 for the elasticity of $R \& D$ productivity with respect to production workers means that a $10 \%$ increase in the number of production workers implies a $1.8 \%$ increase in R\&D productivity. Together with changes in the optimal amount of R\&D labor employed, this accounts for the $10 \%$ increase in the expected number of patents suggested in column 1. The elasticities with respect to the other independent variables are generally of the same order as magnitude. A $10 \%$ increase in the number of patents in the surrounding MSA implies a $2.2 \%$ increase in R\&D productivity, which is not significantly different from the effect of the firm's own production workers. With an elasticity of 0.085 , other employment has a smaller effect.

Table 7 explores how the probability of investment, the expected patents conditional on where large firms face lower R\&D capital costs is worked out in appendix B 
investment, and the underlying R\&D productivity change with the covariates. The base scenario in column 1 is an MSA with all variables set to the mean, except that the number of production workers is zero ("no plant"). In this case, the expected number of patents conditional on investment is 4.3 , and the probability of investment is $3.5 \%$, multiplying to yield an unconditional expectation of 0.15 patents. In an MSA with an average-sized plant (column 2), the expected number of patents conditional on investment is 23 , the probability of investment $53 \%$, and the unconditional expectation therefore 15 patents. Compared to the base scenario R\&D productivity is 2.5 times. The third column performs the experiment of "doubling the MSA" by setting population, within industry employment and the number of patents to twice the respective mean. This has an only minor impact on the firm's patenting: R\&D productivity increases by $3 \%$. The negative effect of population size is therefore slightly more than counteracted if patents and industry employment increase proportionately.

The aggregate effect of production workers on patents is large. The estimated model predicts that if all sample firms stopped producing in the US, instead of inventing about 15,000 patents in five years, they would invent only 3,000. In the terms of the model, R\&D is less productive in the absence of the spillovers and hence firms invest less into it, leading to a radically diminished number of patents overall. Of course this is a merely hypothetical exercise - I do not consider how any of the other quantities in the model may change in response. Nevertheless, this figure demonstrate that the effect of production workers on R\&D productivity is of an economically important magnitude.

\section{$5.2 \quad$ Further Findings}

Having established the key result that manufacturing and R\&D activity are significantly co-located at the firm level, I now turn to more nuanced findings about the drivers of industrial innovation at the firm-MSA level. Do other MSA attributes, in particular universities, matter for patenting in this sample? Which set of patents contributes to the positive effect of other local patents? Do production workers outside the MSA affect the firm's patenting inside the MSA? And finally, how particular are these results to the chemical industry? 


\subsubsection{Academic research has no significant effect}

Table 8 shows that other innovative or academic characteristics of an MSA do not matter for corporate patents. I control for the number of doctorate-granting universities in the MSA, federal funds for academic R\&D that universities in the MSA receive 27 the share of advanced and professional degree holders in the MSA population, and whether the MSA is part of a larger consolidated metropolitan area (CMSA). None of these variables helps to predict the number of patents by the sample firms in the MSA.

The finding that academic research does not affect patents is a surprising result, given examples such as Silicon Valley and the results of other studies [e.g. Jaffe, 1989, Furman and MacGarvie, 2007. Hausman, 2011. ÓhUallacháin 1999, however, does not find a significant relationship between research universities and patents in an MSA either, except for small MSAs outside of the manufacturing belt. The fact that academic research is not important for patents in my sample can be explained by two considerations: First, the sample only includes large, mature companies, and while there is no effect for this set of firms, there may well be an important effect of academic research for smaller companies and start-ups. Secondly, patents may not pick up the R\&D that the sample firms perform close to universities. For example, firms may perform basic research, which does not lead to patentable results, next to universities. In $R \& D$ cooperations between a firm and a university, patents may be assigned to the university and only later sold to the firm.

\subsubsection{Contrasting effects of patents in same technology versus same industry}

The results above indicate a large and positive effect of other patents in the MSA that is hardly diminished when other measures of MSA research environment are included in the estimation. I find that this effect is driven by patents in related technology classes as the firms'. Patents in the same product industry as the firm, interestingly, have a negative effect.

To measure how similar overall MSA patenting is to the firm's, I determine the patent class, subcategory and category in which the firm has the largest number of patents, combined over all MSAs for the years 1983-1987. The United States Patent and Trademark Office (USPTO) defines roughly 400 patent classes, which have been aggregated to 36 sub-categories and six categories by

\footnotetext{
${ }^{27}$ This data has been compiled by Robert Hunt and Gerald Carlino.
} 
Hall et al. 2001]. A firm patents in several different patent classes, and assigning the firm's most frequent patent class to all patents is an approximation ${ }^{28}$ To construct the number of patents in the firm's primary 2-digit SIC code, I use a probabilistic concordance between patent classifications and the SIC system that has been developed by Silverman, Johnson and Kerr [see Kerr, 2008]. On average, within a given MSA a firm will find 5 other patents in its modal patent class, 31 in its modal subcategory, 95 in its modal category, and 62 in its own 2-digit SIC industry. Patents in the same class, subcategory or category are not identical to patents in the same industry: The probability that a patent that belongs to the firm's modal patent subcategory is assigned to SIC 28 is slightly less than 50\%. While the definition of patent classes is based on the firm's technologies, the definition of SIC codes is based on the firm's products.

Table 9 includes these various measures of patents in the estimation, together with the overall number of MSA patents. As demonstrated in columns 1-3, the effect of patents in the firm's modal patent class, subcategory or category is positive and significant. The coefficients on patents in the same subcategory or category is about three times as large as the coefficient on patents in the same patent class since a patent class is represents a relatively narrow definition. At the same time, the effect of the unweighted number of patents vanishes to zero, which is expected if only patents in the same group are relevant. In column 4, the coefficient on patents in the same SIC industry is negative and significant, while the coefficients on total patents and employment in the same industry become significantly positive. These results hold up in columns 5 and 6 , where patents in the same subcategory or category and patents in the same SIC industry are included simultaneously. For patents in similar technological fields, then, agglomeration is beneficial, while for patents in the same product market it is detrimental. The negative effect of patents in the same industry is potential evidence for competition or poaching effects that arise between firms that patent, and not just operate, in the same industry. For example, a firm may be in direct competition with other innovators in its own industry, but collaborate with those that use similar technologies in other

${ }^{28}$ Alternatively, one could weight the MSA patents by the share of the firm's patents in each group:

$$
\text { WeightedPatents }=\sum_{k} \frac{\text { Patents }_{\text {Firm }, k}}{\text { Patents }_{F i r m}} *\left(\text { Patents }_{M S A, k}-\text { Patents }_{M S A, F i r m, k}\right)
$$

where $k$ indexes patent classes, subcategories, or categories. If this weighted sum of other patents is large, the distribution of other patents in the MSA across groups is similar to the firm's. The conclusions are the same as when using only the group with the largest share. 
industries.

\subsubsection{Production workers in close MSA surroundings matter}

Production workers in a $100 \mathrm{~km}$ ring around the MSA positively affect patents in the MSA, as well, while production workers beyond this distance do not. I construct disjoint "rings" around an MSA which consist of counties whose centroids are within a 100, 200, 500, 1000 or $1500 \mathrm{~km}$ radius of the MSA centroid. The $100 \mathrm{~km}$ ring consists of all counties with centroid at a distance less than $100 \mathrm{~km}$ from the MSA centroid but that do not belong to the MSA itself; the 200km ring consists of all counties with centroid at a distance less than $200 \mathrm{~km}$ but more than $100 \mathrm{~km}$ from the MSA centroid, and so on. In table 10 production workers in these disjoint rings around the MSA enter into the model, first individually and then jointly in the last column. The effects are statistically indistinguishable from zero beyond the $100 \mathrm{~km}$ ring. The point estimates decrease almost monotonically as the rings are further removed from the MSA. Within-firm linkages are therefore not contained within MSA boundaries, but decay with geographic distance from the MSA. The fact that the estimate is zero for large distances further validates the estimation approach.

\subsubsection{Results not particular to chemical industry}

Table 11 shows that the positive effect of plants on R\&D is not unique to the chemical industry. Columns 2 and 3 contain estimates for instrument (SIC 38) ${ }^{29}$ and electronics (SIC 36) manufacturers ${ }^{30}$ In both of these industries $R \& D$, and patents, play an important role. For instruments, the coefficient on production workers is even higher than for chemicals, while for electronics it is about the same. In column 4, I use a pooled sample of manufacturing industries other than chemicals and the coefficient on production workers remains of similar magnitude. Co-location benefits of R\&D and manufacturing are therefore not particular to firms in the chemical industry, but are a more general phenomenon in manufacturing industries.

\footnotetext{
29

${ }^{30}$ SIC 36 does not include computers. Definitions of these industries are as follows: SIC 38 - "Measuring, Analyzing, And Controlling Instruments; Photographic, Medical And Optical Goods; Watches And Clocks"; SIC 36 - "Electronic And Other Electrical Equipment And Components, Except Computer Equipment".
} 


\subsection{Robustness}

\subsubsection{Alternative definition of variables}

Table 12 shows that the results are robust to measuring production activity differently, using citation-weighted patents, aggregating at the CMSA level, using 1992 as base year, and dropping pharmaceutical firms from the sample.

In column 1 I use indicators for production worker quartiles, rather than the number of production workers itself, to control for the size of a production plant. Plants below the median do not matter for production at all, while plants in the fourth quartile have twice the effect of plants in the third quartile. The effect of production workers is therefore related to the scale of production activity, not just its existence. If production scale is measured by a plant's capital stock instead of its production workers, as in column 2 , the coefficient is equally significant, but the implied elasticity or R\&D productivity with respect to plant capital stock is only half the size of the elasticity with respect to production workers.

A particular concern may be that if patents at plants are systematically less valuable than patents that are not with plants, the importance that production plays for R\&D may be overstated. Column 3 shows that weighting patents by the number of citations they receive does not alter the estimates, and that therefore heterogeneity in the value of patents is not biasing the coefficients ${ }^{31}$

Since I assume that inventors live and work within one spatial unit, aggregation at too small a scale could yield misleading results. In column 4 I show that results are not sensitive to aggregating the data to consolidated metropolitan areas, which groups together MSAs that constitute a larger metro area. The CMSA New York/Northern New Jersey/Long Island, for example, contains primary MSAs Connecticut, New Jersey and New York.

The quality of the patent assignee - firm link is best from 1986 to 1996, and within this period two economic censuses take place. While I use data from the 1987 census in the main specification, column 5 shows that results are very similar if I use data from the 1992 census and correspondingly shift the dependent variable 5 years forward.

There is considerable heterogeneity across firms even within the two-digit SIC definition of the

\footnotetext{
${ }^{31}$ I maintain the zero-inflated Poisson specification here although the dependent variable, citation-normalized patents, is no longer an integer. The interpretation of these estimates is problematic, and I therefore use unweighted patent counts in the main specification.
} 
chemical industry. In particular, the pharmaceutical industry, which is part of this broad definition of chemicals, may operate and organize differently. Column 6 shows that the estimates are robust to the exclusion of pharmaceutical firms.

\subsubsection{Alternative specifications of the statistical model}

In addition to varying the set of variables and how they are defined, I also verify that the results are not affected by the specific assumptions I make about the fixed costs in section 4. Table 13 compares the estimates obtained from three different versions of the model. The first one is a standard Poisson model, which corresponds to the case without fixed cost in the economic model, see section 4.2 . The second model is the one used so far, which assumes positive fixed cost that are uncorrelated with the explanatory variables. The third model relaxes those restrictions and allows the fixed costs to depend on the explanatory variables via $\gamma_{i m}=\gamma \exp \left(\nu_{X} X_{i m}+\nu_{i m}\right)$. In this case there are two full sets of coefficients, $\beta$ and $\mu$. The effect of independent variable $x$ on the fixed cost $\nu_{x}$ is given by $\nu_{x}=\mu_{x}+\beta_{x}$.

Panel A displays the estimated coefficients and standard errors. In the unconstrained model, $\nu$ is significantly different from zero only for wages and MSA population. Both of these variables are significantly negatively correlated with fixed costs, suggesting that it is cheaper to set up an $\mathrm{R} \& \mathrm{D}$ site in large MSAs with high wages. This is plausible if, for example, fixed costs capture the cost of searching for suitable employees.

Since the interpretation of the estimated coefficients varies between the models, panel B computes the elasticities of the arrival rate and of $R \& D$ productivity with respect to the covariates for each of the three models, analogous to table 6. Standard errors for the elasticities are derived using the delta-method. The point estimates for the Poisson model are slightly larger, but the estimates from the constrained and unconstrained ZIP models are very similar. Generally the difference between the estimates is not statistically significant. As this paper focuses on R\&D

productivity rather than on R\&D fixed cost, and results do not hinge on the specific assumptions about fixed costs, I choose the constrained ZIP model as the main specification. 


\section{Discussion}

The estimate established above, namely that a $10 \%$ increase in production workers is associated with a $1.8 \%$ increase in firm-MSA R\&D productivity, does not capture the causal effect of production scale on $R \& D$ productivity for several reasons. First of all, omitted variables which affect both $R \& D$ productivity and the location of production sites may induce a positive correlation between them even if there is no direct link. Secondly, the estimate may be partially driven by spillovers operating in the reverse direction, from $\mathrm{R} \& \mathrm{D}$ to production. I argue that, while I cannot rule out that some of the magnitude of the estimated effect is driven by endogeneity, neither omitted variables nor reverse causality can explain the effect entirely. I then discuss possible explanations for the link between production and $R \& D$, how they fit with the model presented here, and their plausibility in light of the empirical results.

\subsection{Omitted variables}

The estimates do not seem to be biased by omitted MSA-wide or firm-wide variables. To eliminate this possibility, I control for MSA or firm fixed effects in the standard Poisson model; a zero-inflated Poisson model with fixed effects is computationally prohibitive here. As columns 1-3 of table 14 show, additional MSA or firm characteristics do not significantly reduce the effect of production workers. Since the simple Poisson model, which corresponds to zero fixed cost in the structural model, delivers results consistent with those of the ZIP model that I use as main specification (see table 13), I conclude that omitted firm- or MSA-level variables are not driving the results. An omitted variable that could bias the estimates has therefore to vary at the firm-MSA level.

In the specification presented here, however, it is impossible to distinguish unobserved firmMSA level heterogeneity that correlates with production and $R \& D$ productivity from spillovers between production and R\&D. For example, a firm may locate most of its activities in the MSA where its founders live - simply because it likes the MSA, and not because it is profitable to locate activities together. I assess in how far this may be driving the estimates by controlling for headquarter employment in the MSA. If firms located R\&D and production together only because

they prefer a certain MSA over others, we would expect them to co-locate them with headquarters, and headquarter employment to wash out the effect of production workers on R\&D. The location 
of headquarters, however, may also be endogenously determined by R\&D productivity, and for this reason the main specification does not include headquarter employment. Column 5 of table 14 shows that the estimated effect of production workers is not entirely driven by the location of firm headquarters. Headquarter employment has a significantly positive effect on R\&D productivity, and while the coefficient on production workers drops by about $30 \%$, it is still positive and highly significant. This observation makes me confident that the colocation of production and R\&D is not exclusively attributable to unobserved firm preferences for MSAs. Without the possibility to determine the exact magnitude of these preferences, however, the estimates presented in section 5 have to be interpreted as the combined effect of spillovers and unobserved firm-MSA tastes.

\subsection{Reverse causality}

The second reason why the estimate may not be interpreted as a causal effect is reverse causality. The model here emphasizes the location choice for $R \& D$ in response to given plants, but a firm may consider co-location benefits when it decides on where to establish plants. In this case, plants are located in an MSA precisely because $R \& D$ is also located there. If spillovers between $R \& D$ and plants operate in both directions, part of the estimated effect may stem from the benefit of R\&D on manufacturing.

To demonstrate that reverse causality can only explain a small part of the estimates, I look at whether plants predate patents or the other way around. This is complicated by the fact that the patent database used here goes back to 1975 only, and that patents are a stochastic flow, i.e. if no patent is observed in one year it does not mean that the firm did perform $R \& D$ that year. Notwithstanding these complications, table 15 gives an idea of the ages of patents and plants. In panel A I consider all firm-MSA observations with both patents from 1988-1992 and plants in 1987; these are 359 observations that heavily contribute to the estimated effect of production workers on patents. Patents occur for the first time after 1987 in $22 \%$ of these observations. In $90 \%$ of observations a plant existed in the MSA already prior to 197832 For those observations for which it is possible to infer whether the patent or the plant occurred first, panel B tabulates the gap between those events. In only $10 \%$ of cases patents predate plants, and in three-quarters the patent

\footnotetext{
${ }^{32}$ This may or may not be the plant that the firm operates there today - it may have closed down and started-up again between then and 1987.
} 
occurred five or more years after the first plant. The bulk of the estimate is therefore explained by observations where the plant existed before the patents.

\subsection{Alternative explanations for the estimated effect}

As the above discussion illustrates, this paper does not claim to estimate the causal effect of production workers on patenting. Rather, it shows that a firm's production plants and patents tend to locate together, beyond the degree predicted by the external environment. As long as this pattern is the result of an optimized location decision, it suggests that there are important linkages between production and $\mathrm{R} \& \mathrm{D}$ within the firm that benefit from geographic proximity. The model in section 3 expresses these linkages in terms of $R \& D$ productivity gains. Here I discuss alternative explanations for the colocation of production and plants, and in how far they are consistent with the evidence.

First, a firm may seek to concentrate its activities in a small number of MSAs to minimize monitoring and set-up costs. This contradicts the results from the unconstrained specification in table 13, which shows that production workers have a positive effect on $R \& D$ fixed costs, if they have an affect at all. If production and $R \& D$ locate together, the effect of production workers on R\&D fixed costs should be negative. I do not rule out, however, that proximity to production reduces the cost of $\mathrm{R} \& \mathrm{D}$ inputs, for example by sharing equipment or labor. Neither the model nor the empirical evidence aim to distinguish between such cost advantages and productivity gains.

Secondly, the coefficient on production workers could pick up a direct effect of R\&D labor on $R \& D$ output if production workers performed R\&D. Several pieces of evidence support the view that production workers invent at most a negligible share of patents. A recent survey of inventors finds that about $80 \%$ of US inventors in chemical fields have a $\mathrm{PhD}$ degree Walsh and Nagaoka, 2009. In addition, US patent law defines that only those who contributed ideas can be named as inventor on a patent, precluding as inventors workers who merely execute experiments. I furthermore observe that patents at plants receive more citations, have a lower share of self-citations, and score higher in terms of originality and generality than patents that appear in MSAs where the firm only operates an R\&D lab ${ }^{33}$ If patents at plants were mainly invented by production workers, we would expect

\footnotetext{
${ }^{33}$ For the definition of the originality and generality indeces, see [see Hall et al. 2001. I use the Auxiliary Establishment Survey to identify stand-alone R\&D establishments of the sample firms.
} 
them to be incremental improvements of the existing production technology and to receive fewer citations, have a larger share of self-citations, and score lower in terms of originality and generality.

I do not rule out that production workers patent in some cases, in particular in industries where production is sophisticated. In this situation, production and $R \& D$ are linked in a more immediate way than the model suggests, namely by sharing the same inputs. A location choice model for $\mathrm{R} \& \mathrm{D}$ would be inappropriate if patents were simply a by-product of operating a plant, however. This is clearly not the case: About one quarter of patents occur in MSAs in which the firm does not have a plant, and most inventors are not production workers, as discussed above.

\section{Conclusion}

Firm-internal linkages between production and R\&D play an important role for the location of industrial innovation in the US. This paper establishes this fact by estimating the importance of a firm's production plants for the location of its patents, while controlling for firm-external sources of knowledge spillovers. In the context of the model presented here, the elasticity of R\&D productivity with respect to production workers is 0.18 . This implies that a firm is more than twice as productive at R\&D in an MSA with one of its plants than in an otherwise identical MSA without a plant. Other patents in the MSA have a similar positive effect on firm R\&D, while academic research does not play an important role in this sample.

The ambition of this paper is not to estimate the causal effect of production workers on patenting, but rather to show that production plants are an important factor for R\&D location that has been neglected in the discussion of knowledge spillovers. I overcome limitations of previous studies by using combined patent and census data, which allow me to track a firm's innovative and production activities at the MSA level. Relying on patent data to study spillovers bears some challenges, however. I restrict the main sample to large chemical firms to optimize the bridge between firms and patent assignees and the degree to which patents capture innovation. To make statements about $R \& D$ productivity, I explain unobserved R\&D input levels within a structural model. The resulting estimates cannot isolate the effect of production workers from unobserved firm- and MSA-specific tastes. Furthermore, they may be partially driven by plants locating in response to R\&D, rather than the other way around. Even this reverse causality argument assumes, 
however, that plants and $\mathrm{R} \& \mathrm{D}$ benefit from locating together.

The patterns observed in this paper likely mask heterogeneity across firms, industries, and time periods. Even when restricted to large chemical manufacturers, the sample contains firms with different $R \& D$ processes, for which proximity between production and R\&D is of different importance. Interactions between $\mathrm{R} \& \mathrm{D}$ and production may also change over the lifecycle of production technologies, with emerging technologies depending more strongly on the colocation of $\mathrm{R} \& \mathrm{D}$ and production. My results derive from data for the 1980s and 1990s, and since then new communication technologies may have reduced the cost of geographic distance. Case studies of particular industries and periods could be valuable tools to further shed light on the links between production and innovation.

The research agenda that this paper points to entails two directions: First, it is important to understand why innovation and production are often located together within a firm, and how linkages between production and R\&D operate. Based on conversations with R\&D scientists in the chemical industry, my impression is that interactions between $R \& D$ and production vary across the stages of an $R \& D$ project. At the onset of a research project, $R \& D$ employees need to understand which problems production faces, and for this they need to talk to the people involved. After a new process or product has been developed, scaling it up requires the careful calibration of parameters to a particular facility. More systematic research on this topic is needed though. Second, it is worthwhile to study whether my results extend to the global level, and to quantify the effect that the off-shoring of production has on on domestic innovation. The answer has important implications for economic policy.

\section{References}

Ufuk Akcigit and William R. Kerr. Growth through heterogeneous innovations. NBER Working Paper No. 16443, November 2010.

Thomas J. Allen. Managing the flow of technology. MIT Press, Cambridge, MA, 1977.

Björn Ambos. Foreign direct investment in industrial research and development: A study of German MNCs. Research Policy, 34(4):395 - 410, 2005.

Mohammad Arzaghi and J. Vernon Henderson. Networking off Madison Avenue. Review of Economic Studies, 75(4):1011-1038, October 2008.

David B. Audretsch and Maryann P. Feldman. R\&D spillovers and the geography of innovation and production. The American Economic Review, 86(3):pp. 630-640, June 1996. 
Natarajan Balasubramanian and Jagadeesh Sivadasan. What happens when firms patent? new evidenc from US economic census data. The Review of Economics and Statistics, 93(1):126-146, February 2011.

Gerald A. Carlino and Robert M. Hunt. What explains the quantity and quality of local inventive activity? Brookings-Wharton Papers on Urban Affairs, pages 65-123, 2009.

Gerald A. Carlino, Satyajit Chatterjee, and Robert M. Hunt. Urban density and the rate of invention. Journal of Urban Economics, 61(3):389 - 419, 2007.

Gerald A. Carlino, Jake K. Carr, Robert M. Hunt, and Tony E. Smith. The agglomeration of r\&d labs. Federal Reserve bank of Philadelphia Working Paper, 11-42:577-598, September 2011.

Antonio Ciccone and Robert E. Hall. Productivity and the density of economic activity. The American Economic Review, 86(1):54-70, March 1996.

Stephen S. Cohen and John Zysman. Manufacturing matters: The myth of the post-industrial economy. Basic Books, New York, 1987.

Jason Dedrick, Kenneth L. Kraemer, and Debora Dunkle. Offshore new product development: Survey results. Mimeo, University of California Irvine, February 2009.

Garardine DeSanctis, Jeffrey T. Glass, and Ingrid Morris Ensing. Organizational designs for r\&d. The Academy of Management Executive, 16(3):55-66, August 2002.

Jeffrey Furman and Megan MacGarvie. Academic science and the birth of industrial research laboratories in the U.S. pharmaceutical industry. Journal of Economic Behavior \& Organization, 63(4):756-776, August 2007.

Jeffrey L. Furman, Margaret K. Kyle, Iain Cockburn, and Rebecca M. Henderson. Public \& private spillovers, location and the productivity of pharmaceutical research. Annales d'économie et de statistique, 79-80, 2006.

Edward L. Glaeser, José A. Scheinkman, and Andrei Shleifer. Economic growth in a cross-section of cities. Journal of Monetary Economics, 36(1):117-143, August 1995.

Zvi Griliches. Patent statistics as economic indicators: A survey. Journal of Economic Literature, 28(4):1661-1707, December 1990.

Bronwyn Hall, Adam Jaffe, and Manuel Trajtenberg. The NBER patent citation data file: Lessons, insights and methodological tools. NBER Working Paper No. 8498, November 2001.

Dietmar Harhoff, Francis Narin, F. M. Scherer, and Katrin Vopel. Citation frequency and the value of patented inventions. Review of Economics and Statistics, 81(3):511-15, 1999.

Jerry Hausman, Bronwyn H. Hall, and Zvi Griliches. Econometric models for countdata with an application to the patents-R\&D relationship. Econometrica, 52(4):909-938, July 1984.

Naomi Hausman. Effects of university innovation on local economic growth and entrepreneurship. Job Market Paper, 2011.

J. Vernon Henderson and Yukako Ono. Where do manufacturing firms locate their headquarters? Journal of Urban Economics, 63(2):431-450, March 2008. 
Adam B. Jaffe. Real effects of academic research. The American Economic Review, 79(5):957-970, December 1989.

Adam B. Jaffe, Manuel Trajtenberg, and Rebecca Henderson. Geographic localization of knowledge spillovers as evidenced by patent citations. The Quarterly Journal of Economics, 108(3):pp. 577-598, August 1993.

Martin Kenney and Richard Florida. The organization and geography of Japanese R\&D: Results from a survey of Japanese electronics and biotechnology firms. Research Policy, 23(3):305 - 322, May 1994.

William Kerr. Ethnic scientific communities and international technology diffusion. The Review of Economics and Statistics, 90(3):518 - 537, 2008.

William Kerr. Breakthrough inventions and migrating clusters of innovation. Journal of Urban Economics, 67:46-60, 2010.

William R. Kerr and Shihe Fu. The survey of industrial R\&D-patent database link project. Journal of Technology Transfer, 33(2):173-186, April 2008.

Mikko Ketokivi and Jyrki Ali-Yrkkö. Unbundling R\&D and manufacturing: Postindustrial myth or economic reality? Review of Policy Research, 26(1-2), 2009.

Diane Lambert. Zero-inflated poisson regression, with an application to defects in manufacturing. Technometrics, 34(1):1-14, February 1992.

Richard C. Levin, Alvin K. Klevorick, Richard R. Nelson, and Sidney G. Winter. Appropriating the returns from industrial research and development. Brookings Papers on Economic Activity, 1987(3):783-831, 1987.

Andrew Liveris. Make it in America: The Case for Re-Inventing the Economy. John Wiley and Sons, Inc., Hoboken, NJ, 2011.

Sergey Lychagin, Joris Pinkse, Margaret E. Slade, and John Van Reenen. Spillovers in space: Does geography matter? NBER Working Paper 16188, July 2010.

Edward J. Malecki. Corporate organization of R and D and the location of technological activities. Regional Studies, 14(3):219-234, June 1980.

Edwin Mansfield. Patents and innovation: An empirical study. Management Science, 32(2):173-181, February 1986.

Myriam Mariani. Next to production or to technological clusters? the economics and management of R\&D location. Journal of Management and Governance, 6(2):131-152, 2002.

Enrico Moretti. Workers' education, spillovers, and productivity: Evidence from plant-level production functions. The American Economic Review, 94(3):656-690, June 2004a.

Enrico Moretti. Human capital externalities in cities. In J. Vernon Henderson and Jacques-François Thisse, editors, Cities and Geography, volume 4 of Handbook of Regional and Urban Economics, pages 2243 - 2291. Elsevier, 2004b.

Breandán ÓhUallacháin. Patent places: Size matters. Journal of Regional Science, 39(4):613-636, November 1999. 
Ariel Pakes and Zvi Griliches. Patents and R\&D at the firm level: A first report. Economics Letters, $5(4): 377-381,1980$.

Gary Pisano and Willy Shih. Restoring american competitiveness. Harvard Business Review, JulyAugust 2009.

Lowell W. Steele. Innovation in Big Business. Elsevier, New York, 1975.

Grid Thoma, Salvatore Torrisi, Alfonso Gambardella, Dominique Guellec, Bronwyn H. Hall, and Dietmar Harhoff. Harmonizing and combining large datasets - an application to firm-level patent and accounting data. NBER Working Paper No. 15851, March 2010.

Jerry Thursby and Marie Thursby. Here or There? A Survey of Factors in Multinational R\&D Location. Report to the Government-University-Industry Research Roundtable. National Academy of Sciences, National Academy of Engineering, and Institute of Medicine of the Nationl Academies, 2006.

Christophe van den Bulte and Rudy K. Moenaert. The effects of R\&D team co-location on communication patterns among R\&D, marketing, and manufacturing. Management Science, 44(11): S1-S18, November 1998.

John P. Walsh and Sadao Nagaoka. Who invents?: Evidence from the japan-us inventor survey. Mimeo, July 2009. 
Table 1: Distribution of total patents

\begin{tabular}{l|rr|rr} 
& \multicolumn{3}{|c|}{ SIC 28 - Chemicals } & \multicolumn{3}{c}{ Manufacturing Industries } \\
Total patents & \# Firms & Share & \# Firms & Share \\
\hline \hline 0 & 16 & $12.5 \%$ & 128 & $15.4 \%$ \\
$1-4$ & 22 & $17.2 \%$ & 189 & $22.8 \%$ \\
$5-9$ & 15 & $11.7 \%$ & 116 & $14.0 \%$ \\
$10-19$ & 14 & $10.9 \%$ & 105 & $12.7 \%$ \\
$20-49$ & 18 & $14.1 \%$ & 121 & $14.6 \%$ \\
$50-99$ & 10 & $7.8 \%$ & 65 & $7.8 \%$ \\
$100-200$ & 11 & $8.6 \%$ & 36 & $4.3 \%$ \\
$200-$ max & 22 & $17.2 \%$ & 70 & $8.4 \%$ \\
\hline Sum & 128 & $100.0 \%$ & 830 & $100.0 \%$
\end{tabular}

Notes: Firms are multi-unit firms in the NSF R\&D Survey 1986-1996. Columns on the left contain data for 128 firms with primary SIC code 28 . Patents are measured over the period 1988-1992. Columns on the right contain data for 830 firms with primary SIC codes 20, 22, 24-27, 29-30, 32-38. For data sources see appendix. 
Table 2: Distribution of patenting MSAs

\begin{tabular}{l|rr}
$\begin{array}{l}\text { \# different MSAs with } \\
\text { patents }\end{array}$ & \multicolumn{2}{|c}{ SIC 28 - Chemicals } \\
\# Firms & Share \\
\hline \hline 1 & 24 & $21.4 \%$ \\
2 & 16 & $14.3 \%$ \\
$3-4$ & 21 & $18.8 \%$ \\
$5-9$ & 19 & $17.0 \%$ \\
$10-19$ & 20 & $17.9 \%$ \\
$20-$ max & 12 & $10.7 \%$ \\
\hline Sum & 112 & $100.0 \%$
\end{tabular}

Notes: Firms are multi-unit firms in the NSF R\&D Survey 1986-1996 with at least one patent and with primary SIC code 28 . Patents are measured over the period 1988-1992. For data sources see appendix. 
Table 3: Distribution of patents across MSAs, averaged over chemical firms

\begin{tabular}{l|rrr} 
& \multicolumn{3}{|c}{ MSAs } \\
\# Patents in MSA & Number & Share & Share if >0 \\
\hline \hline 0 & 306 & $97.71 \%$ & \\
1 & 2.88 & $0.92 \%$ & $40.2 \%$ \\
$2-4$ & 2.26 & $0.72 \%$ & $31.5 \%$ \\
$5-9$ & 0.69 & $0.22 \%$ & $9.59 \%$ \\
$10-14$ & 0.27 & $0.08 \%$ & $3.70 \%$ \\
$15-49$ & 0.59 & $0.19 \%$ & $8.28 \%$ \\
$50-149$ & 0.32 & $0.10 \%$ & $4.47 \%$ \\
$150-$ max & 0.16 & $0.05 \%$ & $2.29 \%$ \\
\hline Sum & 313 & $100.00 \%$ & $100.00 \%$
\end{tabular}

Notes: Figures represent averages across 128 firms, which are multi-unit firms in the NSF R\&D Survey 1986-1996 with primary SIC code 28. For data sources see appendix. 
Table 4: Summary Statistics of Estimation Sample

\begin{tabular}{lrrrrr} 
& \multicolumn{1}{c}{$(1)$} & $(2)$ & $(3)$ & $(4)$ & $\begin{array}{c}(5) \\
\text { Variable }\end{array}$ \\
\hline \hline Patents & Unit & \multicolumn{1}{c}{ Period } & \multicolumn{1}{c}{ Mean } & \multicolumn{1}{c}{ SD } & Mean if $>0$ \\
Production Workers & Firm XSA & $1988-1992$ & 0.381 & 10.7 & 16.63 \\
Other Patents & Firm x MSA & 1987 & 5.32 & 66.89 & 171.18 \\
Other Employment Own SIC & Firm x MSA & $1983-1987$ & 538 & 1101 & \\
Median Wage excluding own SIC (\$ thousands) & Firm x MSA & 1987 & 2,915 & 6,436 \\
Population & MSA & 1987 & 11.3 & 1.52 \\
Total Firm Employment & MSA & 1987 & 609,412 & $1,028,513$ \\
& Firm & 1987 & 6,870 & 12,400 \\
Number of Research Universities & & & & \\
Federal Academic R\&D (\$ thousands) & MSA & 1987 & 0.588 & 1.13 \\
Share of Population with Advanced Degree & MSA & $1987-1988$ & 72,428 & 189,610 \\
CMSA Dummy & MSA & 1990 & 0.0699 & 0.0297 \\
CMSA Population excluding MSA & MSA & 1990 & 0.204 & 0.404
\end{tabular}

\begin{tabular}{|c|c|c|c|c|c|}
\hline Other Patents Class & Firm $\times$ MSA & & 5.28 & 21.3 & \\
\hline Other Patents Subcategory & Firm $\times$ MSA & & 31.2 & 85.1 & \\
\hline Other Patents Category & Firm $\times$ MSA & & 95.2 & 221 & \\
\hline Other Patents Own SIC & Firm $\times$ MSA & & 62.1 & 145 & \\
\hline Head Quarter Employment & Firm x MSA & 1987 & 2.98 & 75.9 & 285.45 \\
\hline \# Firms & 128 & & & & \\
\hline \# MSAs & 313 & & & & \\
\hline \# Firm-MSA Observations & 40,064 & & & & \\
\hline
\end{tabular}

Notes: Sample consists of firms in R\&D survey 1986-1996 and with largest share of employees in SIC 28, "Chemicals and Allied Products". For data sources see appendix. 


\section{Table 5: Main Estimation Results}

\begin{tabular}{|c|c|c|c|c|}
\hline & $(1)$ & $(2)$ & $(3)$ & $(4)$ \\
\hline \multirow[t]{2}{*}{ Production Workers } & $0.386 * * *$ & $0.394 * * *$ & $0.357 * * *$ & $0.366 * * *$ \\
\hline & $(0.051)$ & $(0.052)$ & $(0.048)$ & $(0.050)$ \\
\hline \multirow[t]{2}{*}{ Other Patents, MSA } & 0.073 & $0.394 * * *$ & 0.107 & $0.445 * * *$ \\
\hline & $(0.086)$ & $(0.105)$ & $(0.084)$ & $(0.113)$ \\
\hline \multirow[t]{2}{*}{ Other Employment SIC, MSA } & 0.114 & $0.170 *$ & 0.119 & $0.176 *$ \\
\hline & $(0.080)$ & $(0.092)$ & $(0.083)$ & $(0.094)$ \\
\hline \multirow[t]{2}{*}{ Population, MSA } & & $-0.517 * * *$ & & $-0.534 * * *$ \\
\hline & & $(0.164)$ & & $(0.168)$ \\
\hline \multirow[t]{2}{*}{ Total Firm Employment } & & & $0.221 * * *$ & $0.225 * * *$ \\
\hline & & & $(0.043)$ & $(0.043)$ \\
\hline \multirow[t]{2}{*}{ Median Wage, MSA } & -0.683 & -0.941 & -0.752 & -1.069 \\
\hline & $(0.759)$ & $(0.707)$ & $(0.784)$ & $(0.740)$ \\
\hline \multirow[t]{2}{*}{$\beta 0$} & 1.742 & $6.829 * * *$ & -0.353 & $4.956 *$ \\
\hline & $(1.713)$ & $(2.392)$ & $(1.975)$ & $(2.708)$ \\
\hline \multirow[t]{2}{*}{$\mu 0$} & 1.718 & -3.386 & $3.631 *$ & -1.693 \\
\hline & (1.699) & $(2.410)$ & $(1.953)$ & $(2.723)$ \\
\hline Y & 31.79 & 31.30 & 26.52 & 26.12 \\
\hline $\mathrm{N}$ & 40064 & 40064 & 40064 & 40064 \\
\hline$\|$ & -24939 & -24224 & -24183 & -23445 \\
\hline
\end{tabular}

Notes: Estimates from zero-inflated Poisson model with restriction $\beta=-\mu$. Standard errors in parentheses clustered th the firm level. ${ }^{*} p<=10 \%,{ }^{* *} p<=5 \%, * * * p<=1 \%$. 
Table 6: Elasticities

(1) (2)

Elasticity of

with respect to...

Production Workers Expected Patents

R\&D Productivity

$0.966^{* * *}$
$0.177^{* * *}$

Other Patents, MSA

(0.132)

(0.057)

Other Employment SIC, MSA

$1.175 * * *$

$0.215 * *$

(0.291)

(0.087)

Population, MSA

$0.463 * \quad 0.0848 * *$

(0.267)

(0.036)

$-1.41 * * * \quad-0.258 * * *$

(0.417) (0.094)

Total Firm Employment

$0.595^{* * *} \quad 0.109 * *$

(0.132) (0.052)

Median Wage, MSA

$-2.82$

(1.779)

Notes: Computations use estimates in column 4 of table 5. Standard errors are derived using the delta-method. See text for details. 


\section{Table 7: Illustration of Estimates}

(1)

Baseline: No plant production workers $=0$, all
(2)

Average plant

production workers $=171$

Expected number of patents
Arrival rate if selected
Probability of selection
R\&D Productivity (index)

$$
\text { other }=\text { mean }
$$

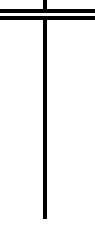

Notes: In each column, the expected number of patents, arrival rate conditional on selection, probabilty of selection and relative R\&D productivity are computed for a different set of independent variables. Independent variables are equal to the mean if not otherwise mentioned. Estimates correspond to table 5, column 4. 
Table 8: Additonal Measures of MSA R\&D Environment

\begin{tabular}{|c|c|c|c|c|c|}
\hline & $(1)$ & $(2)$ & (3) & $(4)$ & $(5)$ \\
\hline \multirow[t]{2}{*}{ Production Workers } & $0.367 * * *$ & $0.365 * * *$ & $0.366 * * *$ & $0.367 * * *$ & $0.366 * * *$ \\
\hline & $(0.050)$ & $(0.048)$ & $(0.050)$ & $(0.050)$ & $(0.050)$ \\
\hline \multirow[t]{2}{*}{ Other Patents, MSA } & $0.454 * * *$ & $0.456 * * *$ & $0.443 * * *$ & $0.419 * * *$ & $0.413 * * *$ \\
\hline & $(0.110)$ & $(0.124)$ & $(0.132)$ & $(0.114)$ & $(0.114)$ \\
\hline \multirow[t]{2}{*}{ Other Employment SIC, MSA } & $0.180 *$ & $0.173 *$ & $0.176 *$ & $0.167 * *$ & $0.159 *$ \\
\hline & $(0.097)$ & $(0.098)$ & $(0.105)$ & $(0.084)$ & $(0.082)$ \\
\hline \multirow[t]{2}{*}{ Population, MSA } & $-0.611 * * *$ & $-0.507 * * *$ & -0.553 & $-0.512 * * *$ & $-0.519 * * *$ \\
\hline & $(0.201)$ & $(0.182)$ & $(0.439)$ & $(0.152)$ & $(0.157)$ \\
\hline \multirow[t]{2}{*}{ Total Firm Employment } & $0.227 * * *$ & $0.226 * * *$ & $0.225 * * *$ & $0.225 * * *$ & $0.227^{* * *}$ \\
\hline & $(0.042)$ & $(0.043)$ & $(0.043)$ & $(0.042)$ & $(0.042)$ \\
\hline \multirow[t]{2}{*}{ Median Wage, MSA } & -1.029 & -1.097 & -1.098 & -1.551 & -1.818 \\
\hline & $(0.740)$ & $(0.769)$ & $(0.836)$ & $(1.134)$ & $(1.289)$ \\
\hline \multirow[t]{2}{*}{ Number Research Universities } & 0.045 & & & & \\
\hline & $(0.046)$ & & & & \\
\hline \multirow[t]{2}{*}{ Federally-funded Academic R\&D } & & -0.012 & & & \\
\hline & & $(0.047)$ & & & \\
\hline \multirow[t]{2}{*}{ Share Advanced Degree } & & & 0.0215 & & \\
\hline & & & $(0.453)$ & & \\
\hline \multirow[t]{2}{*}{ CMSA Dummy } & & & & 0.2695 & \\
\hline & & & & $(0.433)$ & \\
\hline \multirow[t]{2}{*}{ Population, CMSA without MSA } & & & & & 0.1206 \\
\hline & & & & & $(0.156)$ \\
\hline \multirow[t]{2}{*}{$\beta 0$} & $5.723 * *$ & $4.728 *$ & 5.071 & $5.9848 *$ & $5.2401 *$ \\
\hline & $(2.797)$ & $(2.431)$ & $(3.122)$ & 3.4867 & 2.8347 \\
\hline \multirow[t]{2}{*}{$\mu 0$} & -2.455 & -1.458 & -1.808 & -2.724 & -1.992 \\
\hline & $(2.843)$ & $(2.460)$ & $(3.217)$ & $(3.559)$ & $(2.873)$ \\
\hline$\gamma$ & 26.27 & 26.29 & 26.10 & 26.06 & 25.73 \\
\hline N & 40064 & 40064 & 40064 & 40064 & 40064 \\
\hline II & -23410 & -23432 & -23444 & -23362 & -23357 \\
\hline
\end{tabular}

Notes: Estimates from zero-inflated Poisson model with restriction $\beta=-\mu$. Standard errors in parentheses clustered at the firm level. ${ }^{*} p<=10 \%,{ }^{*} p<=5 \%,{ }^{* * *} p<=1 \%$. 


\section{Table 9: Other Patents in Related Fields}

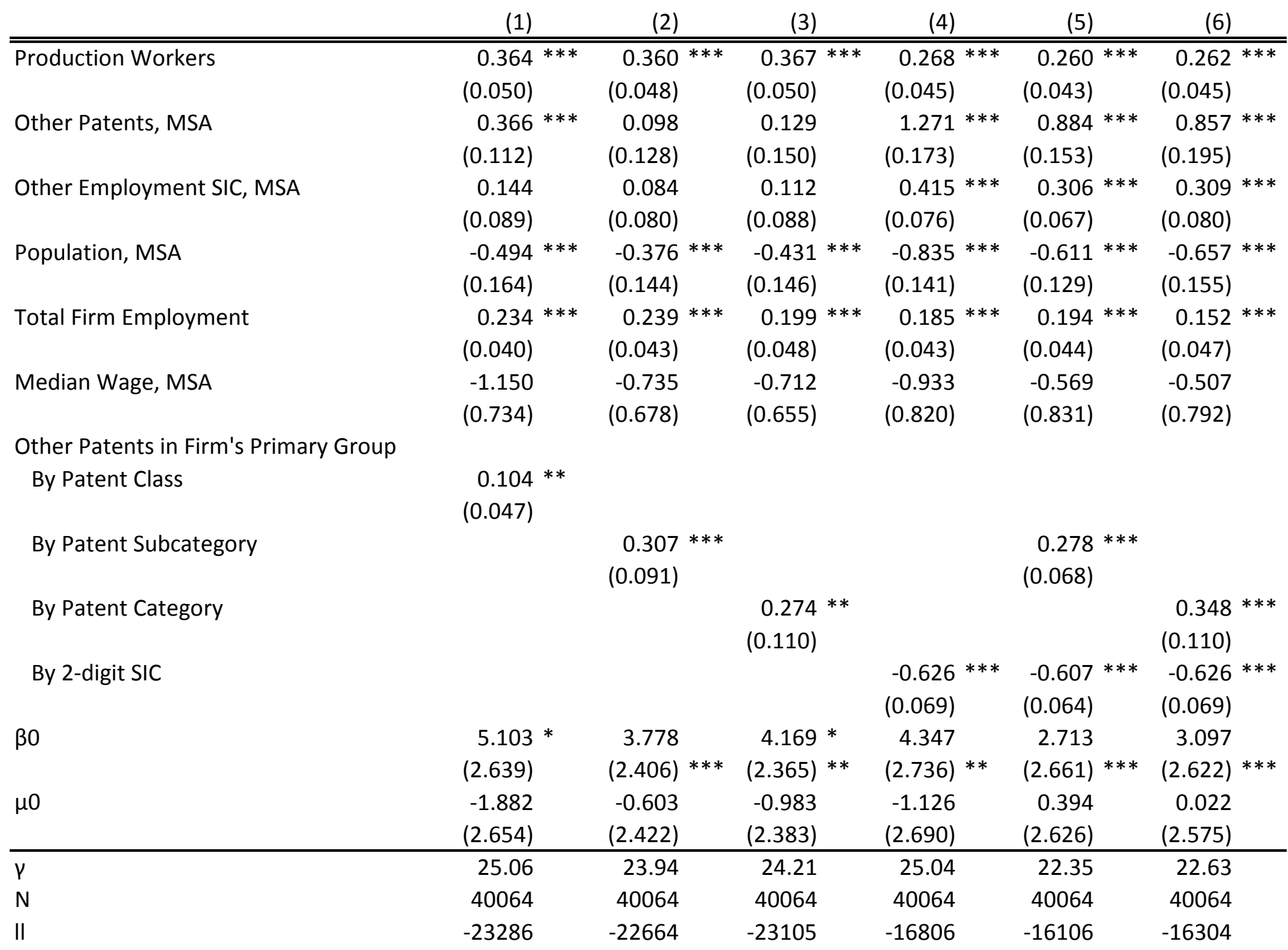

Notes: Estimates from zero-inflated Poisson model with restriction $\beta=-\mu$. Standard errors in parentheses clustered at the firm level. $* \mathrm{p}<=10 \%,{ }^{*} \mathrm{p}<=5 \%, * * * \mathrm{p}<=1 \%$. 
Table 10: Spatial Decay of the Effect

\begin{tabular}{|c|c|c|c|c|c|c|}
\hline & $(1)$ & $(2)$ & (3) & (4) & $(5)$ & $(6)$ \\
\hline \multirow[t]{2}{*}{ Production Workers } & $0.370 * * *$ & $0.363 * * *$ & $0.366 * * *$ & $0.368 * * *$ & $0.365 * * *$ & $0.367^{* * *}$ \\
\hline & $(0.051)$ & $(0.051)$ & $(0.051)$ & $(0.049)$ & $(0.049)$ & $(0.050)$ \\
\hline \multirow[t]{2}{*}{ Other Patents } & $0.422 * * *$ & $0.451 * * *$ & $0.450 * * *$ & $0.448^{* * *}$ & $0.441 * * *$ & $0.413 * * *$ \\
\hline & $(0.110)$ & $(0.113)$ & $(0.114)$ & $(0.111)$ & $(0.113)$ & $(0.115)$ \\
\hline \multirow[t]{2}{*}{ Other Employment SIC } & 0.130 & $0.161 *$ & 0.151 & $0.165 *$ & $0.181 *$ & 0.122 \\
\hline & $(0.086)$ & $(0.088)$ & $(0.097)$ & $(0.099)$ & $(0.101)$ & $(0.094)$ \\
\hline \multirow[t]{2}{*}{ Population } & $-0.411 * *$ & $-0.513 * * *$ & $-0.527 * * *$ & $-0.533 * * *$ & $-0.536 * * *$ & $-0.411 * *$ \\
\hline & $(0.164)$ & $(0.170)$ & $(0.170)$ & $(0.168)$ & $(0.170)$ & $(0.168)$ \\
\hline \multirow[t]{2}{*}{ Total Firm Employment } & $0.161 * *$ & $0.187^{* * *}$ & $0.153 * * *$ & $0.194 * * *$ & $0.245^{* * *}$ & $0.132 * *$ \\
\hline & $(0.063)$ & $(0.059)$ & $(0.049)$ & $(0.051)$ & $(0.053)$ & $(0.060)$ \\
\hline \multirow[t]{2}{*}{ Median Wage } & $-1.598 * *$ & -1.144 & -0.849 & -0.953 & -1.073 & $-1.347 *$ \\
\hline & $(0.734)$ & $(0.732)$ & $(0.802)$ & $(0.768)$ & $(0.743)$ & $(0.814)$ \\
\hline \multicolumn{7}{|l|}{ Production Workers in } \\
\hline \multirow[t]{2}{*}{$100 \mathrm{~km}$ ring } & $0.102 * *$ & & & & & $0.096 * *$ \\
\hline & $(0.040)$ & & & & & $(0.039)$ \\
\hline \multirow[t]{2}{*}{$100-200 \mathrm{~km}$ ring } & & 0.036 & & & & 0.005 \\
\hline & & $(0.029)$ & & & & $(0.027)$ \\
\hline \multirow[t]{2}{*}{$200-500 \mathrm{~km}$ ring } & & & $0.053 *$ & & & 0.048 \\
\hline & & & $(0.031)$ & & & $(0.040)$ \\
\hline \multirow[t]{2}{*}{$500-1000 \mathrm{~km}$ ring } & & & & 0.022 & & 0.005 \\
\hline & & & & $(0.027)$ & & $(0.033)$ \\
\hline \multirow[t]{2}{*}{$1000-1500 \mathrm{~km}$ ring } & & & & & -0.014 & -0.034 \\
\hline & & & & & $(0.032)$ & $(0.036)$ \\
\hline \multirow[t]{2}{*}{$\beta 0$} & $5.481 * *$ & $5.213 *$ & $4.917 *$ & $4.891 *$ & $4.874 *$ & $5.191 *$ \\
\hline & $(2.753)$ & $(2.725)$ & $(2.815)$ & $(2.746)$ & $(2.678)$ & $(2.857)$ \\
\hline \multirow[t]{2}{*}{$\mu 0$} & -2.322 & -1.957 & -1.662 & -1.634 & -1.609 & -2.029 \\
\hline & $(2.772)$ & $(2.742)$ & $(2.827)$ & $(2.759)$ & $(2.685)$ & $(2.866)$ \\
\hline$\gamma$ & 23.54 & 25.93 & 25.93 & 25.97 & 26.18 & 23.63 \\
\hline N & 40064 & 40064 & 40064 & 40064 & 40064 & 40064 \\
\hline$\|$ & -22793 & -23360 & -23300 & -23423 & -23435 & -22661 \\
\hline
\end{tabular}

Notes: Estimates from zero-inflated Poisson model with restriction $\beta=-\mu$. Rings are defined to include all counties with county centroid within given distance from MSA centroid. Standard errors in parentheses clustered at the firm level. ${ }^{*} p<=10 \%, * * p<=5 \%, * * * p<=1 \%$. 
Table 11: Other Manufacturing Industries

\begin{tabular}{|c|c|c|c|c|c|c|}
\hline & $\begin{array}{c}\text { Chemicals } \\
(1)\end{array}$ & $\begin{array}{c}\text { Instruments } \\
\text { (2) }\end{array}$ & $\begin{array}{c}\text { Electroni } \\
(3)\end{array}$ & & $\begin{array}{c}\text { Other Mf } \\
\text { (4) }\end{array}$ & \\
\hline \multirow[t]{2}{*}{ Production Workers } & $0.366 * * *$ & $0.603 * * *$ & 0.385 & $* * *$ & 0.344 & $* * *$ \\
\hline & $(0.050)$ & $(0.078)$ & $(0.098)$ & & $(0.032)$ & \\
\hline \multirow[t]{2}{*}{ Other Patents, MSA } & $0.445 * * *$ & $0.406 * *$ & 0.398 & $*$ & 0.344 & $* * *$ \\
\hline & $(0.113)$ & $(0.158)$ & $(0.205)$ & & $(0.123)$ & \\
\hline \multirow[t]{2}{*}{ Other Employment SIC, MSA } & $0.176 *$ & $0.422 * * *$ & -0.163 & $*$ & 0.014 & \\
\hline & $(0.094)$ & $(0.111)$ & $(0.099)$ & & $(0.047)$ & \\
\hline \multirow[t]{2}{*}{ Population, MSA } & $-0.534 * * *$ & $-0.622 * *$ & -0.052 & & -0.258 & $* *$ \\
\hline & $(0.168)$ & $(0.242)$ & $(0.200)$ & & $(0.125)$ & \\
\hline \multirow[t]{2}{*}{ Total Firm Employment } & $0.225 * * *$ & $0.342 * * *$ & 0.289 & $* * *$ & 0.288 & $* * *$ \\
\hline & $(0.043)$ & $(0.057)$ & $(0.055)$ & & $(0.040)$ & \\
\hline \multirow[t]{2}{*}{ Median Wage, MSA } & -1.069 & $-3.111 * *$ & 0.378 & & 0.536 & \\
\hline & $(0.740)$ & $(1.450)$ & $(0.507)$ & & $(0.713)$ & \\
\hline $\mathrm{N}$ & 40064 & 33491 & 44448 & & 257918 & \\
\hline Firms & 128 & 107 & 144 & & 824 & \\
\hline Patents & 15267 & 16171 & 17936 & & 70696 & \\
\hline Patents/Firm & 119 & 151 & 125 & & 85.8 & \\
\hline
\end{tabular}

Notes: Estimates from zero-inflated Poisson model with restriction $\beta=-\mu$. Standard errors in parentheses clustered at the firm level. ${ }^{*} p<=10 \%,{ }^{* *} p<=5 \%,{ }^{* * *} p<=1 \%$. 


\section{Table 12: Robustness Checks}

\begin{tabular}{|c|c|c|c|c|c|c|}
\hline & $\begin{array}{c}\text { Plant-Size } \\
\text { Quartiles } \\
(1) \\
\end{array}$ & $\begin{array}{c}\text { Plant capital } \\
\text { stock } \\
(2) \\
\end{array}$ & $\begin{array}{c}\text { Citation-weighted } \\
\text { (3) } \\
\end{array}$ & $\begin{array}{c}\text { CMSA level } \\
(4) \\
\end{array}$ & $\begin{array}{c}1992 \text { period } \\
\text { (5) } \\
\end{array}$ & $\begin{array}{c}\text { Without Pharma } \\
\text { Firms } \\
(6) \\
\end{array}$ \\
\hline \multirow[t]{2}{*}{ q1dummy } & 0.621 & & & & & \\
\hline & $(0.379)$ & & & & & \\
\hline \multirow[t]{2}{*}{ q2dummy } & 0.049 & & & & & \\
\hline & $(0.216)$ & & & & & \\
\hline \multirow[t]{2}{*}{ q3dummy } & $1.010^{* * *}$ & & & & & \\
\hline & $(0.304)$ & & & & & \\
\hline \multirow[t]{2}{*}{ q4dummy } & $2.001 * * *$ & & & & & \\
\hline & $(0.235)$ & & & & & \\
\hline \multirow[t]{2}{*}{ Plant capital stock } & & $0.187 * * *$ & & & & \\
\hline & & $(0.028)$ & & & & \\
\hline \multirow[t]{2}{*}{ Production Workers } & & & $0.380 * * *$ & $0.466 * * *$ & $0.354 * * *$ & $0.395 * * *$ \\
\hline & & & $(0.051)$ & $(0.075)$ & $(0.037)$ & $(0.063)$ \\
\hline \multirow[t]{2}{*}{ Other Patents } & $0.390 * * *$ & $0.404 * * *$ & $0.517^{* * *}$ & $0.629 *$ & $0.363 * * *$ & $0.461 * * *$ \\
\hline & $(0.109)$ & $(0.116)$ & $(0.192)$ & $(0.202)$ & $(0.114)$ & $(0.133)$ \\
\hline \multirow[t]{2}{*}{ Other Employment SIC } & $0.216 * *$ & $0.193 * *$ & $0.281 * *$ & $0.157 * * *$ & $0.366 * * *$ & 0.142 \\
\hline & $(0.103)$ & $(0.097)$ & $(0.135)$ & $(0.086)$ & $(0.119)$ & $(0.108)$ \\
\hline \multirow[t]{2}{*}{ Population } & $-0.489 * * *$ & $-0.541 * * *$ & $-0.704 * * *$ & $-0.672 * *$ & $-0.441 * * *$ & $-0.551 * * *$ \\
\hline & $(0.162)$ & $(0.170)$ & $(0.223)$ & $(0.288)$ & $(0.166)$ & $(0.203)$ \\
\hline \multirow[t]{2}{*}{ Total Firm Employment } & $0.244 * * *$ & $0.254 * * *$ & $0.210^{* * *}$ & $0.243^{* * *}$ & $0.215^{* * *}$ & $0.197 * * *$ \\
\hline & $(0.039)$ & $(0.039)$ & $(0.052)$ & $(0.046)$ & $(0.048)$ & $(0.046)$ \\
\hline \multirow[t]{2}{*}{ Median Wage } & -1.095 & -1.002 & $-2.032 *$ & -0.848 & $-1.283 *$ & $-1.426 *$ \\
\hline & $(0.757)$ & $(0.771)$ & $(1.079)$ & (1.517) & $(0.763)$ & $(0.819)$ \\
\hline \multirow[t]{2}{*}{$\beta 0$} & 4.585 & $4.773 *$ & $8.349^{* *}$ & 4.519 & 3.309 & $6.416 * *$ \\
\hline & $(2.821)$ & $(2.776)$ & (3.601) & (3.463) & (2.616) & (3.053) \\
\hline \multirow[t]{2}{*}{$\mu 0$} & -1.111 & -1.457 & $9.457 * * *$ & -1.694 & -0.153 & -3.184 \\
\hline & $(2.783)$ & (2.794) & $(0.835)$ & (3.562) & $(2.610)$ & (3.089) \\
\hline $\mathrm{N}$ & 40064 & 40064 & 40064 & 34176 & 40064 & 31300 \\
\hline$\|$ & -24833 & -24416 & -20107 & -20630 & -19284 & -19005 \\
\hline
\end{tabular}

Notes: Estimates from zero-inflated Poisson model with restriction $\beta=-\mu$. Standard errors in parentheses clustered at the firm level. * $p<$ $=10 \%, * * p<=5 \%, * * * p<=1 \%$. 


\section{Table 13: Alternative Statistical Models}

\section{Panel A: Coefficients}

\begin{tabular}{|c|c|c|c|c|c|c|}
\hline & $\begin{array}{c}\text { (1) } \\
\text { Poisson }\end{array}$ & ZIP con & trained & & (3) & \\
\hline & $\beta$ & $\beta$ & $\mu$ & $\beta$ & $\mu$ & $v=\beta+\mu$ \\
\hline Production Workers & $\begin{array}{l}0.730 * * * \\
(0.077)\end{array}$ & $\begin{array}{l}0.366^{* * *} \\
(0.050)\end{array}$ & $\begin{array}{l}-0.366^{* * *} \\
(0.050)\end{array}$ & $\begin{array}{l}0.372 * * * \\
(0.056)\end{array}$ & $\begin{array}{l}-0.261 * * * \\
(0.017)\end{array}$ & $\begin{array}{c}0.111 * \\
(0.060)\end{array}$ \\
\hline Other Patents & $\begin{array}{l}0.758^{* * *} \\
(0.153)\end{array}$ & $\begin{array}{l}0.445^{* * *} \\
(0.113)\end{array}$ & $\begin{array}{l}-0.445^{* * *} \\
(0.113)\end{array}$ & $\begin{array}{l}0.506^{* * *} \\
(0.145)\end{array}$ & $\begin{array}{l}-0.226 * * * \\
(0.040)\end{array}$ & $\begin{array}{c}0.280 \\
(0.153)\end{array}$ \\
\hline Other Employment SIC & $\begin{array}{l}0.267^{* *} \\
(0.109)\end{array}$ & $\begin{array}{c}0.176 * \\
(0.094)\end{array}$ & $\begin{array}{l}-0.176 * \\
(0.094)\end{array}$ & $\begin{array}{r}0.225 \\
(0.138)\end{array}$ & $\begin{array}{r}-0.040 \\
(0.025)\end{array}$ & $\begin{array}{r}0.185 \\
(0.171)\end{array}$ \\
\hline Population & $\begin{array}{l}-0.720 * * * \\
(0.195)\end{array}$ & $\begin{array}{l}-0.534 * * * \\
(0.168)\end{array}$ & $\begin{array}{l}0.534 \\
(0.168)\end{array}$ & $\begin{array}{l}-0.660 * * * \\
(0.207)\end{array}$ & $\begin{array}{r}0.026 \\
(0.043)\end{array}$ & $\begin{array}{l}-0.634^{* * *} \\
(0.233)\end{array}$ \\
\hline Total Firm Employment & $\begin{array}{l}0.458^{* * *} \\
(0.092)\end{array}$ & $\begin{array}{l}0.225^{* * *} \\
(0.043)\end{array}$ & $\begin{array}{l}-0.225^{* * *} \\
(0.043)\end{array}$ & $\begin{array}{c}0.203 * * * \\
(0.053)\end{array}$ & $\begin{array}{l}-0.303^{* * *} \\
(0.033)\end{array}$ & $\begin{array}{r}-0.099 \\
(0.069)\end{array}$ \\
\hline Median Wage & $\begin{array}{r}-0.884 \\
(1.064)\end{array}$ & $\begin{array}{r}-1.069 \\
(0.740)\end{array}$ & $\begin{array}{r}1.069 \\
(0.740)\end{array}$ & $\begin{array}{l}-1.687 * \\
(0.911)\end{array}$ & $\begin{array}{l}-1.276^{* * *} \\
(0.262)\end{array}$ & $\begin{array}{l}-2.963 \text { *** } \\
(1.017)\end{array}$ \\
\hline Constant & $\begin{array}{r}-1.049 \\
(3.893)\end{array}$ & $\begin{array}{c}4.956 * \\
(2.708)\end{array}$ & $\begin{array}{r}-1.693 \\
(2.723)\end{array}$ & $\begin{array}{l}7.623 \text { ** } \\
(3.228)\end{array}$ & $\begin{array}{l}9.119 * * * \\
(0.766)\end{array}$ & \\
\hline $\begin{array}{l}\mathrm{N} \\
\mathrm{II} \\
\mathrm{BIC}\end{array}$ & $\begin{array}{r}40064 \\
-36734 \\
73541\end{array}$ & $\begin{array}{l}40 \\
-23 \\
46\end{array}$ & $\begin{array}{l}64 \\
445 \\
74\end{array}$ & & $\begin{array}{c}40064 \\
-23020 \\
46188\end{array}$ & \\
\hline
\end{tabular}

Notes: Estimates from Poisson (column 1), zero-inflated Poisson model with constraints $\beta=-\mu$ (column 2), and zero-inflated Poisson model without constraints on the parameters (column 3). In the unconstrained ZIP model, $v$ is the effect of the independent variables on fixed cost. Standard errors clustered at the firm level in parentheses. ${ }^{*} p<=10 \%,{ }^{* *} p<=5 \%,{ }^{* * *} p<=1 \%$. 


\section{Table 13: Alternative Statistical Models - ctd}

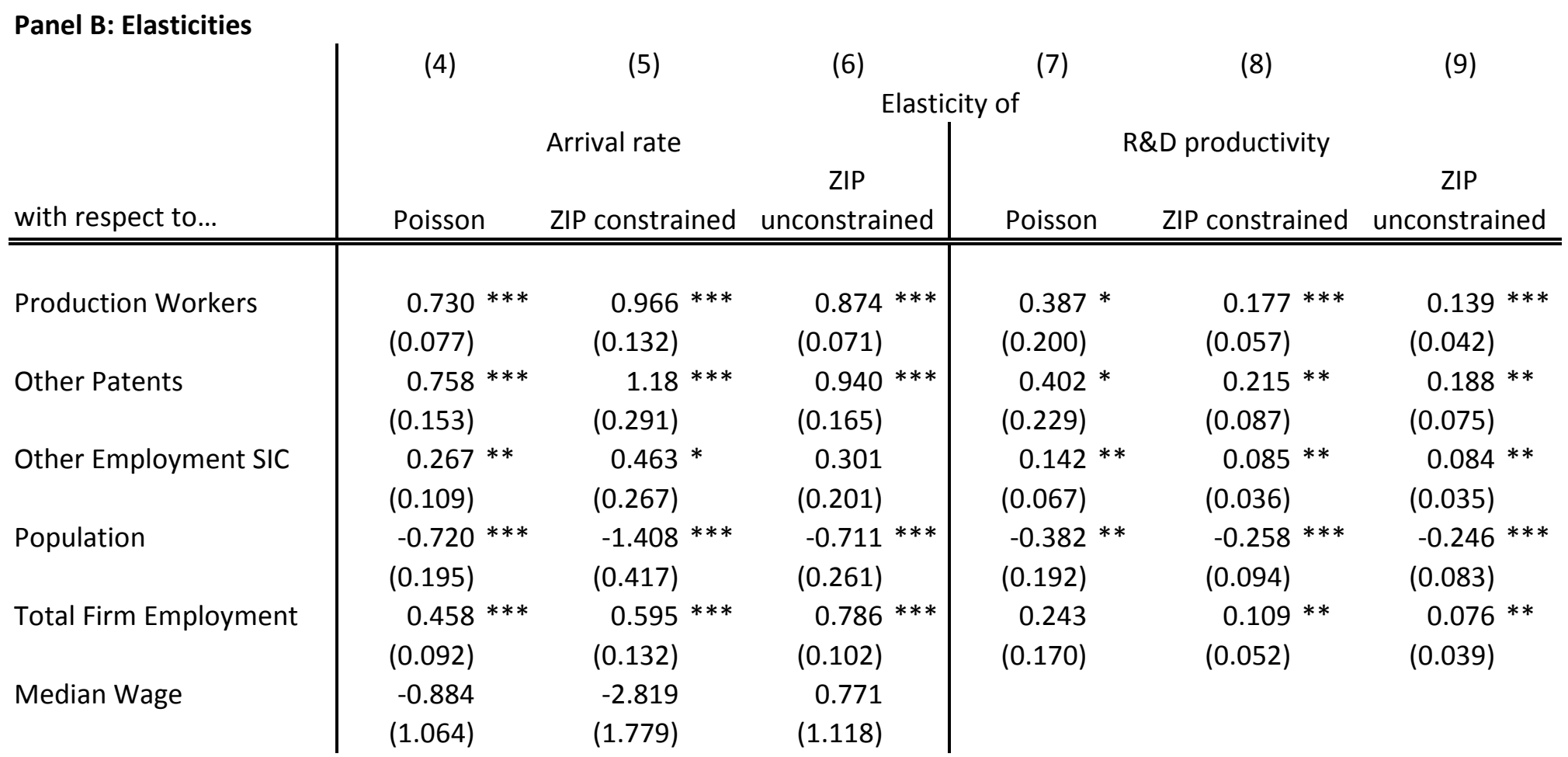

Notes: Elasticities for Poisson model (columns 4 \& 7), zero-inflated Poisson model with constraints $\beta=-\mu$ (columns $5 \& 8$ ), and zero-inflated Poisson model without constraints, based on estimates in table 12, columns 1-3. Elasticities computed at the mean. Standard errors are computed using the delta-method. See text for details. ${ }^{*} p<=10 \%,{ }^{* *} p<=5 \%,{ }^{* * *} p<=1 \%$. 


\section{Table 14: Omitted Variables}

\begin{tabular}{|c|c|c|c|c|c|}
\hline & $\begin{array}{c}\text { Poisson } \\
(1) \\
\end{array}$ & $\begin{array}{c}\text { Poisson w/ MSA } \\
\text { Fixed Effects } \\
(2) \\
\end{array}$ & $\begin{array}{c}\text { Poisson w/ Firm } \\
\text { Fixed Effects } \\
(3) \\
\end{array}$ & $\begin{array}{l}\text { ZIP } \\
(4) \\
\end{array}$ & $\begin{array}{c}\text { ZIP w/ HQs } \\
(5) \\
\end{array}$ \\
\hline Production Workers & $\begin{array}{l}0.730 * * * \\
(0.077)\end{array}$ & $\begin{array}{c}0.666^{* * *} \\
(0.064)\end{array}$ & $\begin{array}{l}0.725^{* * *} \\
(0.080)\end{array}$ & $\begin{array}{l}0.366 \text { *** } \\
(0.050)\end{array}$ & $\begin{array}{c}0.257^{* * *} \\
(0.046)\end{array}$ \\
\hline Other Patents & $\begin{array}{l}0.758 * * * \\
(0.153)\end{array}$ & & $\begin{array}{l}0.637^{* * *} \\
(0.154)\end{array}$ & $\begin{array}{l}0.445 * * * \\
(0.113)\end{array}$ & $\begin{array}{l}0.422 \text { *** } \\
(0.097)\end{array}$ \\
\hline Other Employment SIC & $\begin{array}{l}0.2677^{* *} \\
(0.109)\end{array}$ & & $\begin{array}{l}0.277^{* *} \\
(0.126)\end{array}$ & $\begin{array}{c}0.176 * \\
(0.094)\end{array}$ & $\begin{array}{c}0.155 * \\
(0.082)\end{array}$ \\
\hline Population & $\begin{array}{l}-0.720 * * * \\
(0.195)\end{array}$ & & $\begin{array}{l}-0.649 * * * \\
(0.202)\end{array}$ & $\begin{array}{l}-0.534 * * * \\
(0.168)\end{array}$ & $\begin{array}{l}-0.632 * * * \\
(0.139)\end{array}$ \\
\hline Median Wage & $\begin{array}{r}-0.884 \\
(1.064)\end{array}$ & & $\begin{array}{r}0.378 \\
(0.873)\end{array}$ & $\begin{array}{r}-1.069 \\
(0.740)\end{array}$ & $\begin{array}{l}-1.094 * \\
(0.586)\end{array}$ \\
\hline Total Firm Employment & $\begin{array}{l}0.458 * * * \\
(0.092)\end{array}$ & $\begin{array}{l}0.4611^{* * *} \\
(0.098)\end{array}$ & & $\begin{array}{l}0.225 * * * \\
(0.043)\end{array}$ & $\begin{array}{l}0.253^{* * *} \\
(0.040)\end{array}$ \\
\hline Employment HQs & & & & & $\begin{array}{l}0.234 * * * \\
(0.043)\end{array}$ \\
\hline$\beta 0$ & $\begin{array}{r}-1.049 \\
(3.893)\end{array}$ & MSA FEs & Firm FEs & $\begin{array}{c}4.956 * \\
(2.708)\end{array}$ & $\begin{array}{l}6.350 * * * \\
(1.940)\end{array}$ \\
\hline$\mu 0$ & - & - & - & $\begin{array}{r}-1.693 \\
(2.723) \\
\end{array}$ & $\begin{array}{r}-3.128 \\
(1.950) \\
\end{array}$ \\
\hline Y & - & - & - & 26.12 & 25.08 \\
\hline$N$ & 40064 & 24448 & 35056 & 40064 & 40064 \\
\hline ॥ & -36734 & -25536 & -30230 & -23445 & -19998 \\
\hline
\end{tabular}

Notes: Column 1: Estimates from Poisson model. Standard errors clustered at the firm level in parantheses. Columns 2-3: Estimates from Poisson model with MSA resp. firm fixed effects. Bootstrapped standard errors in parantheses. Columns 4-5: Estimates from zero-inflated Poisson model with restriction $\beta=-\mu$. Standard errors in parentheses clustered at the firm level. $* p<=10 \%,{ }^{* *} p<=5 \%, * * * p<=1 \%$. 
Table 15: Plant and Patent Age Distribution, SIC 28

Panel A

\begin{tabular}{lrrrr} 
& before 1978 & $1978-1982$ & $1983-1987$ & $1988-1992$ \\
\hline \hline first year plant & $90.25 \%$ & $5.57 \%$ & $4.18 \%$ & $0 \%$ \\
first year patent & $52.37 \%$ & $10.58 \%$ & $15.04 \%$ & $22.01 \%$
\end{tabular}

Panel B

\begin{tabular}{rrrr} 
plant - patent age (years) & 0 or less & $1-4$ & 5 or more \\
\hline \hline $10.38 \%$ & $14.21 \%$ & $75.41 \%$
\end{tabular}

Note: Panel A: The universe are all firm-MSA observations with both patents from 1988-1992 and plants in 1987 ( $N=359)$. Percentages indicate the share of these observations for which the first plant resp. patent appeared in a given time period. Panel B: The universe are all firm-MSA observations with both patents from 1988-1992 and plants in 1987 where either the first year a patent occurs is after 1977 or the first year a plant occurs is after $1975(\mathrm{~N}=183)$. Percentages indicate the share of these observations for which the difference between the first year a plant appeared and the first year a patent appeared falls into a certain time span. 


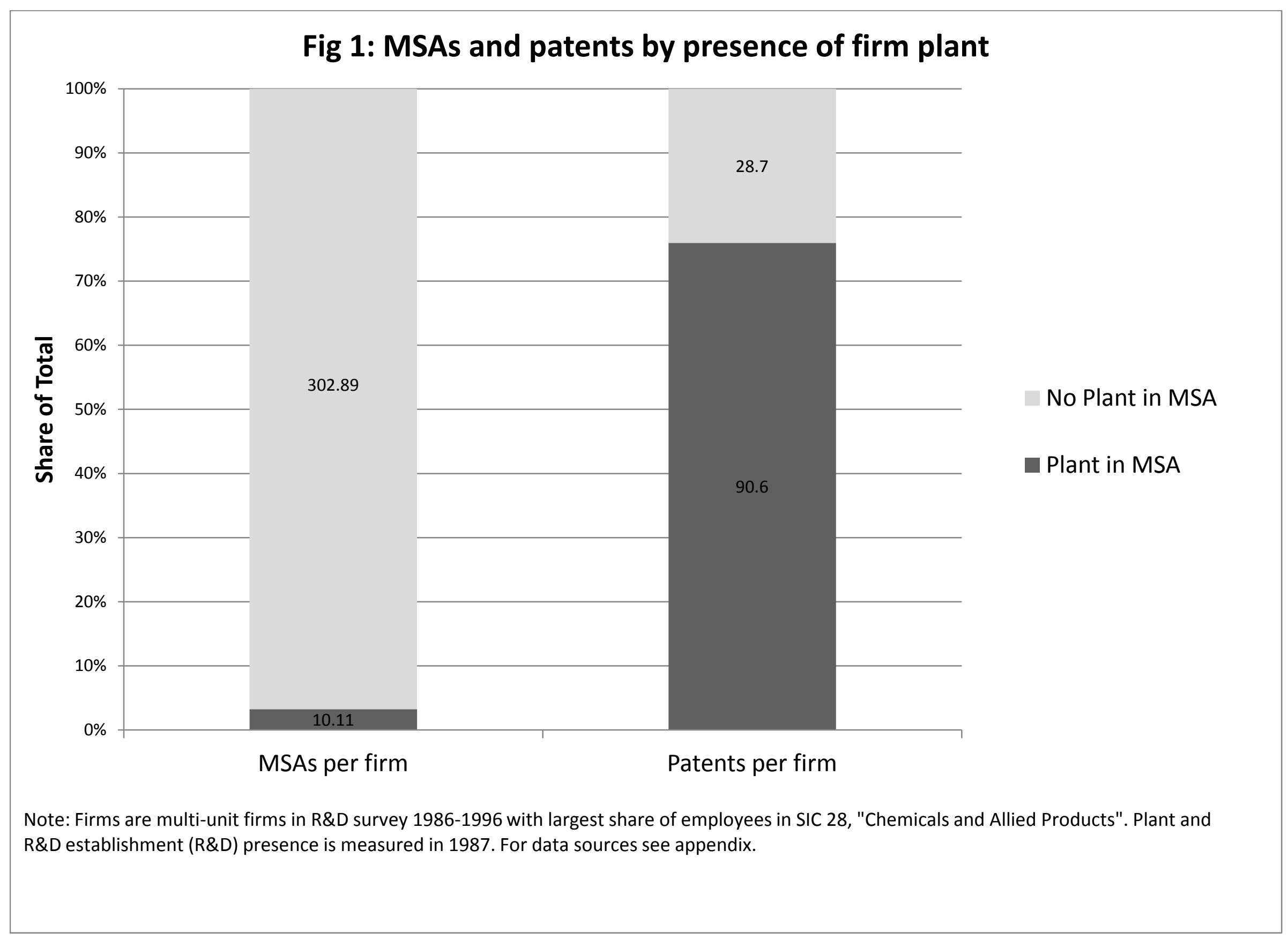




\section{A Appendix: Data}

The patent data cover all patents granted by the United States Patent and Trademark Office (USPTO) 1975-1999. Primarily, the data are taken from the NBER patent file and based on the information included in patent applications. Patent applications contain the name and residential address of one or more of the inventors, which can be used to assign the patent to a geographic place. Carlino and Hunt have matched the original lead inventor address data to county fips codes Carlino et al. [see 2007], and their match provides the basis for the allocation of patents to MSAs. In cases where it is impossible to assign an individual county but possible to assign a unique MSA, for example because street and zip code information are missing but city information is available, I complement their match by assigning MSAs directly.

The USPTO assigns patents to classes, which are not congruent with the SIC system. A concordance has been developed by Silverman, Johnson and Kerr. If patents need to be assigned to a specific industry, I use the concordance based on a patent's industry of manufacture.

Data on a firm's manufacturing activities comes from the quinquennial Census of Manufacturers (CM) in 1987 and 1992. The CM collects detailed data at the plant level, including the county in which the plant is located, the number of employees and the number of employees directly involved in production (production workers), and the primary industry of the plant. Firms in the sample operate multiple plants (13.4 on average), and I assign the 2-digit SIC with the largest employment as the firm's SIC code.

Data on non-manufacturing establishments are taken from the Standard Statistical Establishment List (SSL) in census years 1987 and 1992. The SSL is directly taken from the Business Register and contains data on all employers in the United States from a variety of government agencies. In contrast to the census of manufacturers, which covers only manufacturing plants, the SSL includes all types of establishments that a firm operates, e.g. retail stores and administrative offices. Establishments under common ownership share a common firm identifier. One can infer an establishments function from the "principal processing division" (e.g. "Census of Manufacturers", "Auxiliary Establishment Survey") and the "type of operations" (e.g. "Central Administrative

Office") variable. I use the SSL to compute firm headquarter employment in an MSA and total employment in an MSA by industry. 
I use the Industry R\&D Survey discussed in section 2.2 for data on total firm R\&D expenditures.

The link between patent assignees and firms used here is described in detail by Kerr and Fu, but there are some points to note. Frequently, a firm holds patents under multiple patent assignee names, so in general the match between assignees and firms is many-to-one. Further, Kerr and Fu's link is time-invariant, that is, they match assignee and firm if the assignee name corresponds to the firm name for some year (firm names are pulled from the SSEL in 1987, 1992, 1997) and extend the link back and forth in time (e.g. "abc corporation" which files a patent in 1984 could be matched to "abc corporation" showing up in the SSEL in 1997).

Table A1 specifies the definitions of all the variables used in the estimation, together with their sources, and table A2 displays the correlations between them. 


\section{Table A1: Variable Definitions}

Label

Unit of

Patents

Firm x MSA

1988-1992

US Patent and

Number of patents the firm filed with lead inventor Trademark Office residing in MSA.

\section{Production Workers}

Firm x MSA 1987

Other Patents

Firm x MSA $\quad 1983-1987 \quad$ USPTO

Other Employment Own SIC

Firm x MSA 1987

Median Wage excluding own SIC (\$ MSA thousands)

Population

MSA

Total Firm Employment

Firm

1987

Federal Academic R\&D ( $\$$ thousands) MSA

Number of Research Universities SSEL
(USPTO)

Census of

Manufacturers

Production workers in manufacturing establishments owned by the firm and located in MSA.

Number of patents with lead inventor residing in MSA, less patents by firm in MSA.

Employment within same 2-digit SIC as firm in the MSA, less employment in establishments owned by the firm in the MSA.

Median wage across all establishments in the MSA, excluding establishments in the same two-digit SIC industry as the firm.

Number of people living in the MSA.

Regional Income Statistics, Bureau of Economic Analysis

1987-1988 NSF Survey of Research and Development Expenditures at Universities and Colleges, Carlino and Hunt aggregation

Carnegie Foundation
Number of universities in the MSA with Carnegie Classification "Research I", "Research II", "Doctoral I", or "Doctoral II" in 1987. These universities award 50 or more doctoral degrees annually and receive more than $\$ 15 \mathrm{~m}$ annually in federal support. 
Share of Population with Advanced

Degree

CMSA Dummy

CMSA Population excluding MSA

Other Patents Class

Other Patents Subcategory

Other Patents Category

Other Patents Own SIC

Firm R\&D Expenditures ( $\$$ thousands)

Firm

1987
MSA

MSA

1987

1987

Census Geography

Reference 1993

Regional Income

Statistics, Bureau of

Economic Analysis

$\begin{array}{lll}\text { Firm-MSA } & 1983-1987 \quad \text { USPTO }\end{array}$
Share of the population aged over 25 with an advanced or professional degree in the MSA.

Equal to one if MSA is part of Consolidated Metropolitan Statistical Area (CMSA), else equal to zero.

Number of people living in CMSA less number of people living in MSA.

Number of patents with lead inventor residing in MSA in same patent class as the largest share of the firm's patents 1983-1987 across all MSAs, less firm's patents in MSA in this patent class.

\author{
Firm-MSA 1983-1987
}

USPTO, Hall-Jaffe-

Number of patents with lead inventor residing in MSA in Trajtenberg defintion of same subcategory as the largest share of the firm's patents subcategories 1983-1987 across all MSAs, less firm's patents in MSA in this subcategory.

Firm-MSA 1983-198

USPTO, Hall-JaffeTrajtenberg defintion of same patent category as the largest share of the firm's categories patents 1983-1987 across all MSAs, less firm's patents in MSA in this patent category.

Firm-MSA 1983-1988 USPTO, SilvermanJohnson-Kerr Number of patents with lead inventor residing in MSA in same 2-digit SIC as firm, less firm's patents in MSA.

concordance

Total R\&D expenditures by the firm in $\$$ thousands.
Foundation (NSF)

Survey of Industry

Research and

Development 


\section{Head Quarter Employment}

Firm x MSA 1987

R\&D Establishment Employment

Firm x MSA

1987
National Science Foundation (NSF) Survey of Industry Research and Development SSEL

SSEL
Share of total R\&D expenditures spent on applied research and development as opposed to basic research.

Employment in central administrative offices by the firm in the MSA.

Employment in stand-alone R\&D establishments by the firm in the MSA. 


\section{Table A2: Correlations of Main Variables}

\section{Panel A: Firm-MSA and MSA Variables}

\begin{tabular}{lc|cccccccccccccc} 
& & 1 & 2 & 3 & 4 & 5 & 6 & 7 & 8 & 9 & 10 & 11 & 12 & 13 \\
\hline \hline Patents & 1 & 1.000 & 0.408 & 0.056 & 0.064 & 0.040 & 0.047 & 0.038 & 0.032 & 0.016 & 0.035 & 0.037 & 0.566 & 0.683 \\
Production Workers & 2 & 0.408 & 1.000 & 0.096 & 0.104 & 0.063 & 0.089 & 0.067 & 0.055 & 0.016 & 0.042 & 0.053 & 0.323 & 0.233 \\
Other Patents & 3 & 0.056 & 0.096 & 1.000 & 0.755 & 0.651 & 0.873 & 0.710 & 0.669 & 0.273 & 0.476 & 0.495 & 0.086 & 0.038 \\
Other Employment Own SIC & 4 & 0.064 & 0.104 & 0.755 & 1.000 & 0.481 & 0.729 & 0.575 & 0.469 & 0.147 & 0.380 & 0.479 & 0.104 & 0.041 \\
Median Wage excluding own SIC & 5 & 0.040 & 0.063 & 0.651 & 0.481 & 1.000 & 0.576 & 0.486 & 0.443 & 0.336 & 0.547 & 0.588 & 0.061 & 0.026 \\
Population & 6 & 0.047 & 0.089 & 0.873 & 0.729 & 0.576 & 1.000 & 0.826 & 0.700 & 0.190 & 0.420 & 0.458 & 0.096 & 0.028 \\
Number of Research Universities & 7 & 0.038 & 0.067 & 0.710 & 0.575 & 0.486 & 0.826 & 1.000 & 0.745 & 0.409 & 0.352 & 0.346 & 0.092 & 0.024 \\
Federal Academic R\&D & 8 & 0.032 & 0.055 & 0.669 & 0.469 & 0.443 & 0.700 & 0.745 & 1.000 & 0.421 & 0.315 & 0.287 & 0.069 & 0.027 \\
Share Advanced Degree Holders & 9 & 0.016 & 0.016 & 0.273 & 0.147 & 0.336 & 0.190 & 0.409 & 0.421 & 1.000 & 0.222 & 0.240 & 0.023 & 0.015 \\
CMSA Dummy & 10 & 0.035 & 0.042 & 0.476 & 0.380 & 0.547 & 0.420 & 0.352 & 0.315 & 0.222 & 1.000 & 0.724 & 0.048 & 0.028 \\
CMSA Population excluding MSA & 11 & 0.037 & 0.053 & 0.495 & 0.479 & 0.588 & 0.458 & 0.346 & 0.287 & 0.240 & 0.724 & 1.000 & 0.069 & 0.022 \\
Head Quarter Employment & 12 & 0.566 & 0.323 & 0.086 & 0.104 & 0.061 & 0.096 & 0.092 & 0.069 & 0.023 & 0.048 & 0.069 & 1.000 & 0.471
\end{tabular}

\section{Panel B: Firm-MSA and Firm Variables}

\begin{tabular}{lc|ccccccc} 
& & 1 & 2 & 3 & 4 & 5 & 6 & 7 \\
\hline \hline Patents & 1 & 1.000 & 0.408 & 0.069 & 0.073 & 0.004 & 0.566 & 0.683 \\
Production Workers & 2 & 0.408 & 1.000 & 0.151 & 0.142 & 0.009 & 0.323 & 0.233 \\
Total Firm Employment & 3 & 0.069 & 0.151 & 1.000 & 0.905 & 0.068 & 0.055 & 0.049 \\
Firm R\&D Expenditures (\$ thousands) & 4 & 0.073 & 0.142 & 0.905 & 1.000 & 0.038 & 0.052 & 0.051 \\
Share Applied R\&D & 5 & 0.004 & 0.009 & 0.068 & 0.038 & 1.000 & 0.006 & 0.002 \\
Head Quarter Employment & 6 & 0.566 & 0.323 & 0.055 & 0.052 & 0.006 & 1.000 & 0.471
\end{tabular}

Notes: Sample consists of firms in R\&D survey 1986-1996 and with largest share of employees in SIC 28, "Chemicals and Allied Products". For variable definitions and sources see table A1, for summary statistics see table 3 . 


\section{B Appendix: Model for R\&D Location Choice with Capital}

\section{B.1 Motivation and implications}

The effect of production workers on R\&D productivity is overstated in the basic model if firm size affects $R \& D$ input costs. I show that the elasticity of $R \& D$ productivity with respect to production workers decreases from 0.177 in the basic model to 0.157 in this model with firm-specific capital costs; this difference is not statistically significant.

Large firms may face lower costs of performing $R \& D$ because they are less credit constrained than small firms. In the basic model with labor only, this channel is ignored and it is assumed that firm size affects $R \& D$ through productivity only. The effect of production workers on $R \& D$ productivity is therefore overstated. This model with $R \& D$ capital illustrates the opposite extreme where firm size has no effect on R\&D productivity but impacts the cost of R\&D capital. It therefore serves to compute lower bounds on the elasticities of R\&D productivity.

\section{B.2 Set-up and Assumptions}

The assumptions and notation are the same as in section 3 of the paper, except if otherwise stated. Each firm $i$ decides on an allocation of R\&D capital and labor to cities, described by the vectors $K_{i}=\left(K_{i 1}, \ldots, K_{i m}\right)$ and $L_{i}=\left(L_{i 1}, \ldots, L_{i m}\right)$.

The firm chooses an allocation of $R \& D$ labor to cities that maximizes expected $R \& D$ revenue net costs:

$$
\max _{K, L \in \mathbb{R}_{+}^{M}} E[R(Y)]-C(K, L)
$$

The expected value of $y_{i m}$ is a function of the R\&D inputs $K_{i m}$ and $L_{i m}$ and city-firm specific productivity $A_{i m}$. The marginal productivity of R\&D inputs employed in the city is decreasing:

$$
E\left[y_{i m}\right]=A_{i m} K_{i m}^{a} L_{i m}^{b}, \quad a+b<1, a>0, b>0
$$

The firm's cost of performing R\&D is the sum of the costs incurred in each city, which consist of capital costs $R_{i} K_{i m}$, wages $W_{m} L_{i m}$ and a city-firm specific fixed cost $c_{i m}$ if performing $\mathrm{R} \& \mathrm{D}$. The interest paid on capital varies across firms, but not across locations, while the wage varies across locations but not across firms. The total $\mathrm{R} \& \mathrm{D}$ costs associated with $\mathrm{R} \& \mathrm{D}$ allocation $\left(K_{i}, L_{i}\right)$ are 
therefore:

$$
C\left(K_{i}, L_{i}\right)=R_{i} \sum_{m} K_{i m}+\sum_{m} W_{m} L_{i m}+\sum_{m} c_{i m}\left[L_{i m}>0\right]
$$

\section{B.3 The Firm's R\&D Location Decision}

Under the above assumptions, the firm's profit maximization problem is

$$
\max _{\left\{L_{i}\right\}} \sum_{m}\left(A_{i m} K_{i m}^{a} L_{i m}^{b}-R_{i} K_{i m}-W_{m} L_{i m}-c_{i m}\left[L_{i m}>0\right]\right) .
$$

Let $K_{i m}^{*}$ and $L_{i m}^{*}$ be the optimal capital respectively labor in city $m$. If they are positive, they are given by the first order condition $\frac{\partial E\left[y_{i m}\right]}{\partial K_{i m}}=R_{i}$ and $\frac{\partial E\left[y_{i m}\right]}{\partial L_{i m}}=W_{m}$. Solving out:

$$
\begin{aligned}
K_{i m}^{*} & =\left(a^{1-b} b^{b} R_{i}^{b-1} W_{m}^{-b} A_{i m}\right)^{\frac{1}{1-a-b}} \\
L_{i m}^{*} & =\left(a^{a} b^{1-a} R_{i}-a W_{m}^{a-1} A_{i m}\right)^{\frac{1}{1-a-b}}
\end{aligned}
$$

$K_{i m}^{*}$ and $L_{i m}^{*}$ are positive if and only if the expected $R \& D$ revenue in city $m$ exceeds the fixed cost. $K_{i m}^{*}$ is positive if and only if $L_{i m}^{*}$ is positive, therefore we can reduce the considerations to $L_{i m}^{*}$ :

$$
L_{i m}^{*}>0 \Leftrightarrow A_{i m} K_{i m}^{* a} L_{i m}^{* b}-R_{i} K_{i m}^{*}-W_{m} L_{i m}^{*}-c_{i m} \geq 0 .
$$

Therefore I can write

$$
\begin{aligned}
K_{i m}^{*} & =d_{i m}\left(a^{1-b} b^{b} R_{i}^{b-1} W_{m}^{-b} A_{i m}\right)^{\frac{1}{1-a-b}} \\
L_{i m}^{*} & =d_{i m}\left(a^{a} b^{1-a} R_{i}^{-a} W_{m}^{a-1} A_{i m}\right)^{\frac{1}{1-a-b}}
\end{aligned}
$$

where $d_{i m}$ is an indicator variable,

$$
d_{i m}=\left[c_{i m} \leq\left(a^{\frac{a}{1-a-b}} b^{\frac{b}{1-a-b}}-a^{\frac{a}{1-a-b}} b^{\frac{1-a}{1-a-b}}-a^{\frac{1-b}{1-a-b}} b^{\frac{b}{1-a-b}}\right)\left(R_{i}^{-a} W_{m}^{-b} A_{i m}\right)^{\frac{1}{1-a-b}}\right]
$$

Correspondingly, the optimal arrival rate is

$$
E\left[y_{i m}\right]=d_{i m}\left(a^{a} b^{b} R_{i}^{-a} W_{m}^{-b} A_{i m}\right)^{\frac{1}{1-a-b}} .
$$




\section{B.4 Estimation}

I specify that the firm-city specific $R \& D$ productivity is given by

$$
A_{i m}=\exp \left(g_{0}+X_{i m}^{\prime} g\right)
$$

where $g_{0}$ is a constant and $g$ a parameter vector.

The firm-specific interest rate $R_{i}$ is not observed directly, and I use firm size $S_{i}$ as a proxy for $R_{i}$. I assume that larger firms face lower interest rates, and that the two quantities are related via

$$
\log R_{i}=h_{0}+h \log S_{i}
$$

Plugging this into equations $(28)$ and $(29)$ yields

$$
\begin{aligned}
d_{i m} & =\left[\gamma_{i m} \leq \exp \left(\beta_{0}+\beta_{w} w_{m}+\beta_{S} S_{i}+X_{i m}^{\prime} \beta_{X}\right)\right] \text { and } \\
E\left[y_{i m} \mid X_{i m}\right] & =d_{i m} \exp \left(\beta_{0}+\beta_{W} W_{m}+\beta_{R} R_{i}+X_{i m}^{\prime} \beta_{X}\right)
\end{aligned}
$$

where I have defined

$$
\begin{aligned}
& \beta_{0}=\frac{a \log a+b \log b+g_{0}+a h_{0}}{1-a-b} \quad \beta_{S}=\frac{-a h}{1-a-b} \\
& \beta_{W}=\frac{-b}{1-a-b} \quad \beta_{X}=\frac{g}{1-a-b} \quad \gamma_{i m}=\frac{c_{i m}}{1-a-b} .
\end{aligned}
$$

\section{B.5 Interpretation of estimated coefficients}

The estimated coefficients on firm size $S_{i}$ and wage rate $W_{m}$ translate back into the structural model via

$$
\begin{aligned}
& \beta_{S}=\frac{-a h}{1-a-b} \\
& \beta_{W}=\frac{-b}{1-a-b}
\end{aligned}
$$

To back out $a$ and $b$ from these equations, we would need to know $h$, the parameter that describes the relationship between firm size and capital cost. 
However, the ratio of capital expenditures to labor expenditures is

$$
\frac{R K}{W L}=\left(a^{1-b} b^{b} R^{-a} W^{-b} A_{i m}\right)^{\frac{1}{1-a-b}}\left(a^{a} b^{1-a} R^{-a} W_{m}^{-b} A_{i m}\right)^{\frac{-1}{1-a-b}}=\frac{a}{b},
$$

independent of firm and location. The ratio of capital costs to labor costs can therefore be approximated using data from the firm-level R\&D survey. For firms in the estimation sample (restricted to SIC 28), the ratio between $R \& D$ expenditures for materials and supplies to $R \& D$ expenditures for salaries and wages is 0.24 . Using therefore $\frac{a}{b}=0.24$ and the estimated coefficient on the wage $\beta_{W}=-1.07$ yields

$$
a=0.11 \quad \text { and } \quad b=0.46
$$

Combined with the estimate of $\beta_{S}=0.225$, these parameter values imply $h=-0.89$.

Table A3 compares the elasticities of R\&D productivity from the model with labor only, presented in the main text, to those from the model with capital presented here. As expected, elasticities are smaller in the latter case, but differences are neither economically not statistically significant. 
Table A3: Elasticities of R\&D productivity in model with capital

(1)

(2)

Elasticity of R\&D Productivity in

with respect to... Base model Model with capital

Production Workers

$0.177^{* * *} \quad 0.157$

(0.057)

Other Patents, MSA

$0.215^{* *}$

0.191

(0.087)

Other Employment SIC, MSA

$0.0848 * *$

0.0755

(0.036)

$-0.258 * * *$

$-0.229$

Population, MSA

(0.094)

Total Firm Employment

$0.109 * *$

(0.052)

Median Wage, MSA

Notes: Computations use estimates in column 4 of table 4 . See text for details. 